\title{
Effect of Vesicular Arbuscular Mycorrhizal (VAM) Fungus and Rock- Phosphate Application on the Growth and Biomass of Moringa oleifera Lam. Seedlings under Salinity Stress
}

\author{
Marwa G. S. Frahat ${ }^{1}$ and Mohamed R. A. Shehata ${ }^{2}$
}

\begin{abstract}
Salinity is a devastating environmental stress factor that severely affects plant growth and development. Soil salinity often hinders plant productivity in both natural and agricultural settings. Vesicular Arbuscular mycorrhizal fungal (VAM) symbionts can mediate plant stress responses by enhancing salinity tolerance. Experiments were conducted in a greenhouse at the nursery of the Experimental Station of Forestry and Wood Technology Dept., Faculty of Agriculture, University of Alexandria, Abies region, Alexandria, from June, 2017 to May, 2018 and repeated at the same time in the second season. The obtained results showed that the inoculation with VAM and addition of RP led to enhance the growth significantly, in terms of survival, shoot height, shoot root ratio, root dry weight, shoot dry weight and total dry weight and minerals of the leaves of $M$. oleifera $(\mathrm{N}, \mathrm{P}$ and K\%) compared with the uninoculated ones. Chlorophyll a of M. oleifera was affected by salinity. Na Cl treatments caused a decrease in chlorophyll a and chlorophyll b content in both seasons. The largest increases in plants nutrient uptake ( $N, P$ and $K$ ) and decreasing in Na were observed with the VAM+RP treatment. The inoculated seedlings with VAM induced the highest value in Proline content in the first and second seasons compared with the uninoculated ones.The present study concluded that $(M$. oleifera Lam.) could tolerate salt concentration up to 171.1 $\mathrm{mM}$ in the presence of mycorrhiza. It is recommended; however, to inoculate the seedlings with VAM and $(1 \mathrm{~g} / \mathrm{kg}$ soil) rock-phosphate application to enhance its growth and mitigate salinity stress.
\end{abstract}

Key words: Salinity, Moringa, Rock-phosphate, Proline, Mycorrhiza and VAM.

\section{INTRODUCTION}

Salinity is a devastating environmental stress factor that severely affects plant growth and development (Barnawal et al., 2014). Soil salinity is rapidly increasing with an estimated addition of $0.3-1.5$ million ha of farmland annuals, thereby decreasing crop production by more than 20\% (Porcel et al., 2012; and Food and Agriculture Organization [FAO], 2015). It also renders another 20-46 million ha with decreased capacity for production. Nevertheless, the earth is home to 7.7 billion people with addition of 83 million people every year at the rate of $1.09 \%$ (United Nations [UN], 2018). At the global level, particularly in arid and semiarid regions, salt alters a wide range of metabolic processes, culminating in stunted growth, and minimized enzyme activities and biochemical constituents (Muthukumarasamy and Panneerselvam, 1997). Salinity, furthermore is considered an important constraint, and approximately $7 \%$ of global land has suffered from high salinity, making it unarable (Sheng et al., 2008 and Ruiz-Lozano et al., 2012). Physiologically, salinity reduces enzymes activities and plant growth through osmotic as well as ionic constraints of major physiological and biochemical reactions (Ahmad, 2010; Porcel et al., 2012; Abd_Allah et al., 2015).

Proline accumulation has been first observed in wilting perennial plants (Kemble and MacPherson, 1954) and was later found to be one of the common physiological responses of higher plants when they are exposed to a number of environmental stresses (Verbruggen and Hermans 2008). Proline accumulation has been reported in plants exposed to high salinity (Armengaud, et al. 2004). Proline is the most common osmolyte in plants under stress conditions (Hasegawa et al., 2000) and act as a mediator of osmotic adjustment (Ashraf and Foolad, 2007) and serves as a hydroxyl radical scavenger (Alia et al., 1995). There are accumulating evidences that the production of reactive oxygen species (ROS) is a major damaging factor in plants exposed to different environmental stresses, including salinity (Hernandez et al., 1995). Peroxidase (POX) and catalase (CAT) are involved in the defense mechanisms of plants in response to pathogens by their participation in cell wall reinforcement. Cells under salt stress initially accumulate salts as free osmotica, however, a toxic specific ion effect appears once a certain threshold level of $\mathrm{Na}$ and/ or $\mathrm{Cl}$ accumulation has been reached. An excess of these ions may alter membrane integrity, enzymatic activity, protein and

DOI: 10.21608/asejaiqjsae.2021.167455

${ }^{1}$ Forestry and Wood Technology Department, Faculty of Agriculture,

Alexandria University.

${ }^{2}$ Plant Pathology Department, Faculty of Agriculture,

Alexandria University.

Received March 21, 2021, Accepted, April 28, 2021. 
nucleic metabolism (Hasegawa et al., 2000; Zhu 2001, Zhu and Liming 2002 and Mansour and Salama, 2004).

Plants under stress produce some defense mechanisms to protect themselves from the harmful effect of oxidative stress. ROS scavenging is one among the common defense response against abiotic stresses. ROS scavenging depends on the detoxification mechanism provided by an integrated system of nonenzymatically reduced molecules like ascorbate, glutathione and enzymatic antioxidants (Prochazkova et al., 2001; Shrivali et al., 2003). The primary antioxidant enzyme which converts superoxide to $\mathrm{H}_{2} \mathrm{O}$ and oxygen is superoxide dismutase (SOD) (Alscher et al., 2002). The main enzyme involved in $\mathrm{H}_{2} \mathrm{O}_{2}$ scavenging is also catalase, which decomposes $\mathrm{H}_{2} \mathrm{O}_{2}$ to water and oxygen. SOD and CAT are considered as key components in the antioxidant response system as they regulate the cellular concentration of $\mathrm{O}_{2-}$ and $\mathrm{H}_{2} \mathrm{O}_{2}$ (Van Breusegem et al., 2001).

Moringa oleifera in Pakistan named as sohanjna is a miracle tree having tremendous uses like phytopesticides, afforestation, medicines, water purification, biogas, vegetable etc (Wasif, et al,. 2012). It is naturally found in diverse habitats with an altitude ranging from 600-1800 m (Jama and Yucel 1989). Recently, many uses of moringa have been highlighted and farmers are taking interest to cultivate it as field crop for fodder and vegetable production and as forestry plantation (Chen and Bin, 2020).

Vesicular arbuscular mycorrhizial (VAM) fungi are considered as beneficial symbiotic associations with most plants and play a main role in plant growth under various conditions by modifying the root system and enhancing mobilization and the uptake of several essential elements. They have also been reported to stimulate plant stress tolerance by enhancing systems of enzymatic and nonenzymatic antioxidant defense (Wu et al., 2014; Ahmad et al., 2015. There is a body of evidence for the role of mycorrhizal fungi in disease resistance of the plant per se (Zeng, 2013). It is known that VAM fungi can increase plant growth and productivityunder different conditions, including various soil stresses (Hildebrandt et al., 2007; Miransari et al., 2008; Evelin et al., 2009 and 2011 and Dudhane et al., 2011).

Herewise, this study aimed at pinpointing the effect of mycorrhizal fungi and rock phosphate fertilization on the growth of Moringa oleifera under salinity stress and determination of mineral content $(\%)$ in the treated leaves of Moringa oleifera seedlings.

\section{MATERIALS AND METHODS}

\section{Plant material and growth conditions}

Experiments were conducted in a greenhouse at the nursery of the Experimental Station of Forestry and Wood Technology Dept., Faculty of Agriculture, University of Alexandria, Abies region, Alexandria, from June, 2017 to May, 2018 and repeated at the same time in the second season. Seeds were sown on $18^{\text {th }}$, July 2017 and 2018. Seeds of Moringa oleifera were germinated in a soil mixture of perlite, sand, peatmoss and vermiculite $(1: 1: 1: 1 \mathrm{v} / \mathrm{v})$. Phosphorous as rock phosphate was added at the rate of $0.0,1.0$ and $2.0 \mathrm{~g} / \mathrm{kg}$ soil. Moringa seedlings were 40 - days - old. Half of the total pots were inoculated with the mycorrhizal fingus, Glomus fasciculatum as Moringa seedlings were two months old. The VAM inoculum consisted of soil, clamydospores (Ca 50 spores $\mathrm{g}^{-1}$ inoculum), To Furnish the same soil conditions, control plants were inoculated, yet with sterilized inocula. One month after the artificial inoculation with mycorrhizal fungus, salinization tratments were conducted using five salinity levels $(0$, 42.78, 85.56, 128.24 and 171.1 (mili mole) $\mathrm{mM} \mathrm{Na} \mathrm{Cl}$ ).

\section{Experimental design}

The experimental design consisted of thirty treatments having non- AM inoculated and AM inoculated with three phosphorus levels $(0,0.1 \mathrm{~g}$ and $2 \mathrm{~g} / \mathrm{kg}$ soil) and five salinity levels ( $\mathrm{NaCl}: 0,42.78$, 85.56, 128.24 and 171.1 (mili mole) $\mathrm{mM}$. Pots were arranged in a completely randomized design. The splitsplit plot technique was used in analyzing the data obtained, where the main plot was for phosphorus fertilization, the sub plot was for salinity levels and the sub-sub plot was for inoculation with symbiotic agent.

Table 1. Outline of the source of variation and its degree of freedom (d.f) of the experiment used.

\begin{tabular}{lc}
\hline Source of variance & d.f \\
\hline Replicates & 3 \\
A & 2 \\
Error a & 6 \\
B & 4 \\
AB & 8 \\
Error b & 36 \\
C & 1 \\
AC & 2 \\
BC & 4 \\
ABC & 8 \\
Error c & 45 \\
Total & 119 \\
\hline
\end{tabular}

The data obtained were statistically analyzed according to Snedecor (1956) using SAS ver. 9.1.3 (2007). Four replications were used for each treatment i.e. total 120 pots. Three months after germination, homogenized 
seedlings were selected for the experimental study. Treated seedlings were monitored, cared and all observations were recorded. In addition, root samples were examined for presence of VAM, if any. Growth parameters, notably, shoot height and abnormal symptoms were recorded after one month, seedlings were harvested for further analysis.

\section{Ultrastuctural examination of infected feeder roots with VAM}

Feeder -roots samples were collected, washed free from debris, cut into small pieces ( $3 \mathrm{~mm}$ length), then soaked in a chain of ten concentrations of ethanol solution, 10, 20, 30,----, 100\%, then in xylol. The specimens were soaked in each concentration for 1.0 hour, then dried and fixed for scanning electron microscope (SEM) examination, according to the method described by Hayat, (1991).

\section{Morphological parameters}

The analyzed morphological parameters, survival (\%), shoot height (SH), shoot dry weight (SDW), root dry weight (RDW), total dry weight (TDW) and shoot root ratio (SRR) were recorded.

\section{Biochemical parameters.}

Proline colorimetrically determined according to Marín et al., 2009. The protocol for Chlorophyll a and b was applied to determine its content according to Nagata and Yamashta, 1992, while mineral contents of plants were determined in all seedlings according to Chapman and Pratt, 1961 and Olsen and Sommers, 1982.
Table 2. The chemical analysis of the experimental soil.

\begin{tabular}{lc}
\hline Characteristics & Value \\
\hline $\mathrm{pH}(1$ soil : 2.5 d.w. $)$ & 8.6 \\
E.C. $(\mathrm{mmohs} / \mathrm{cm})$ & 11.5 \\
Anion (mq/100 g soil) & \\
$\mathrm{Cl}^{-}$ & 103 \\
$\mathrm{HCO}_{3}{ }^{-}$ & 2.4 \\
$\mathrm{SO}_{4}^{-}$ & 26.4 \\
$\mathrm{CO}^{-}$ & ----- \\
$\mathrm{Cations}^{--} \mathrm{mq} / 100$ g soil) & \\
$\mathrm{Mg}^{++}$ & 22.3 \\
$\mathrm{Na}^{+}$ & 91.2 \\
$\mathrm{Ca}^{++}$ & 18.3 \\
$\mathrm{~K}^{+}$ & 1.9 \\
\hline
\end{tabular}

\section{RESULTS}

\section{Mycorrhization}

The scanning electron microscope examination has revealed the colonization of extrametrical hyphae of VAM of rootlet cortex cells of inculated seedlings with VAM as shown in (Fig.1). it has also indicated that the feeder roots of Moringa oleifera contained arbuscules of Glomus fasiculatum and its internal hyphae (Fig. 2).

\section{Healthy and growth parameters}

Growth parameters including survival (\%), shoot height $(\mathrm{cm})$, shoot dry weight $(\mathrm{g})$, root dry weights $(\mathrm{g})$, total dry weight $(\mathrm{g})$ and shoot root ratio of Moringa oleifera Lam. seedlings in both seasons are shown in Tables (4, 5, 6, 7 and 8). The present study showed that (Moringa oleifera Lam.) could tolerate salt concentrations up to $171.1 \mathrm{mM}$ in presence of Mycorrhiza. Negative relationship was obtained between salt stress degree and plant growth parameters during the growing seasons.

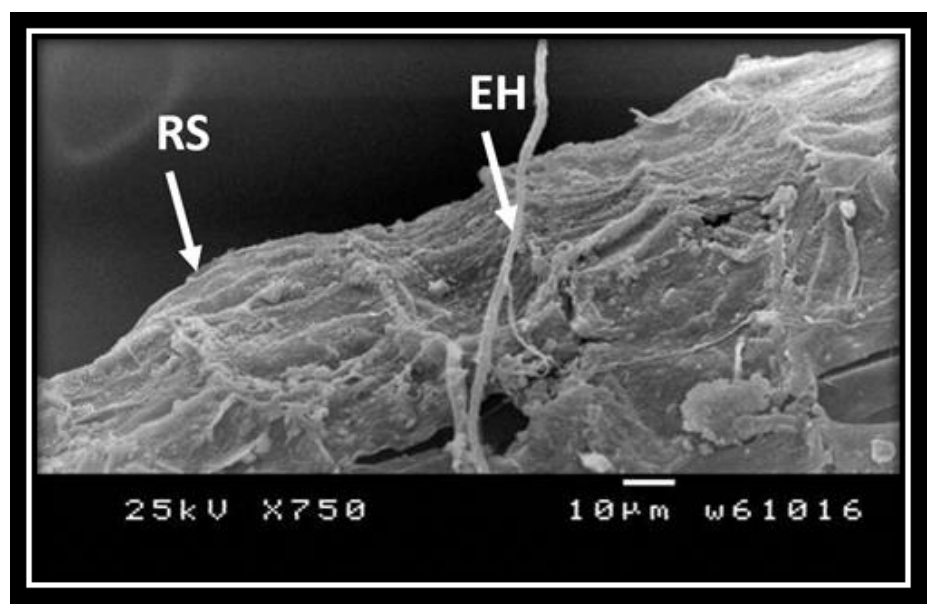

Fig. 1. Scanning electron micrograph indicates root surface (RS) penetrated by extrametrical hyphae of VAM fungus (EH) 

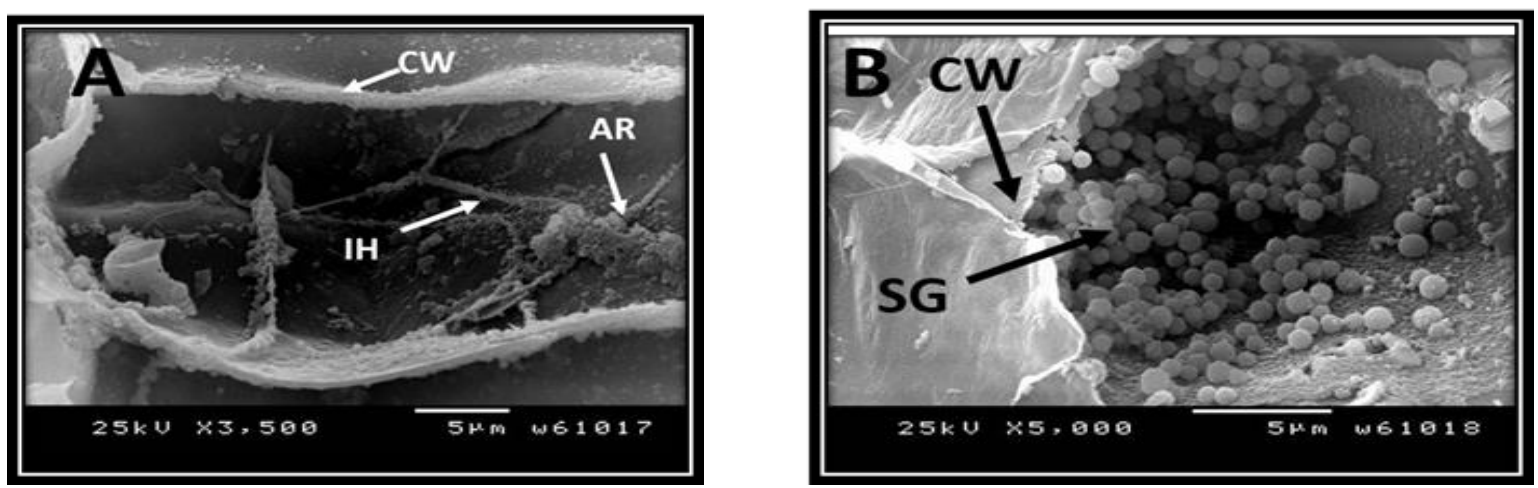

Fig. 2. (A) Scanning electron micrograph (SEM) indicates feeder root of Moringa oleifera contained Arbscules of Glomus fasciculatum. IH: Internal hyhpae, Ar: Arbscule and CW:Cell wall. (B) Mature parenchymateous cells with starch granules (SG) in the cortex of feeder root cell

\subsection{Survival (S) (\%)}

Regardless of the impact of salinity and inoculation with VAM, there is non singnificant differences among $\mathrm{RP}$ level applied in terms of $\mathrm{S}$. There were significant differences among the impacts of salinity levels. However, the lowest $\mathrm{S}$ was obtained in the seedlings treated with $\mathrm{S}_{5}$ in both seasons, $(62.50$ and $70.83 \%$ for first and second season, respectively) (Table 3).

The inoculation with VAM has also brought about the highest $\mathrm{S}$ in both seasons (96.67 and $98.33 \%$ for first and second season, respectively) (Table 3).

Table 3. Survival (\%) of inoculated and uninoculated seedlings of Moringa oleifera Lam. with VAM, unfertilized and fertilized with RP under five levels of salinity

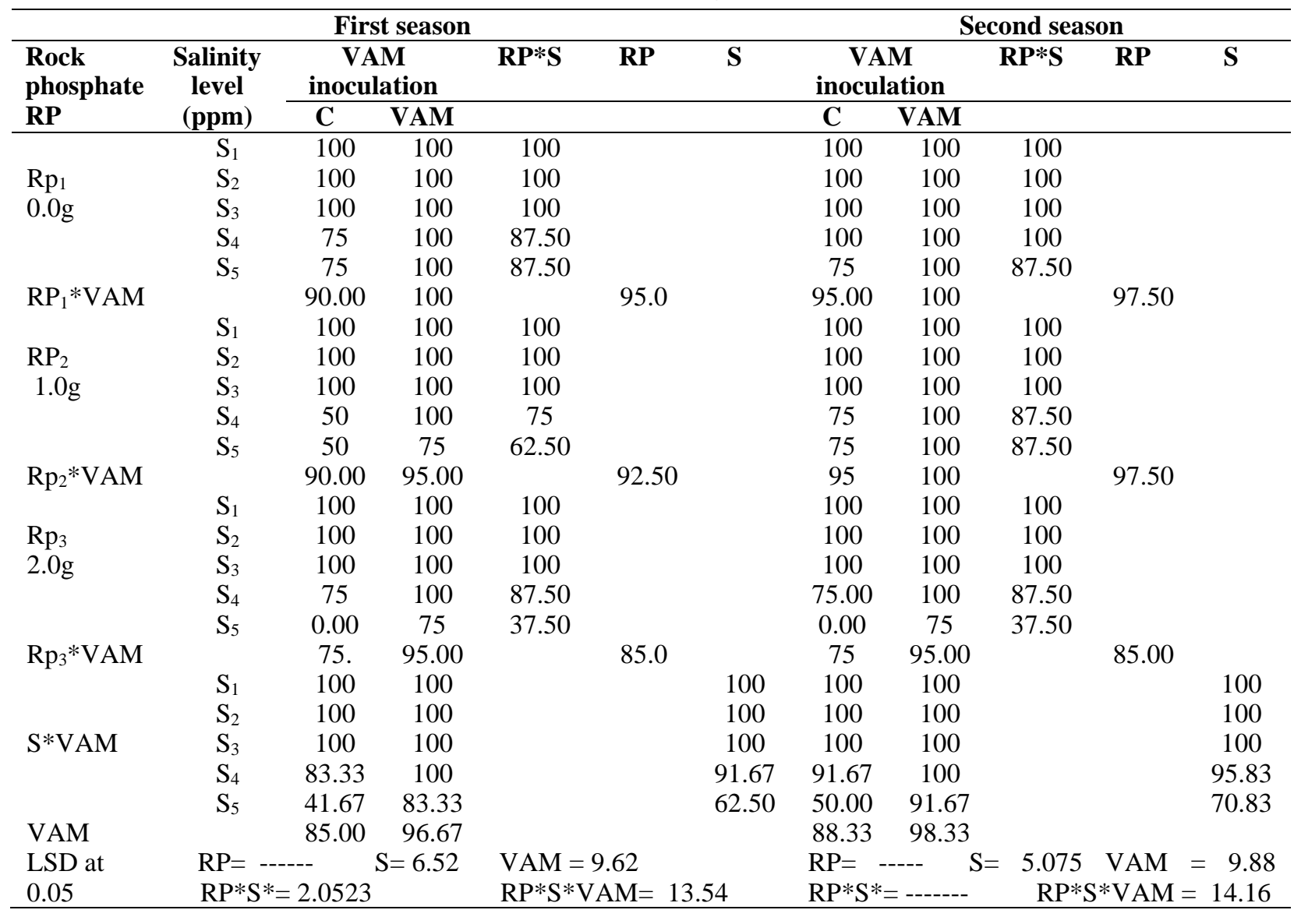




\subsection{Shoot height $(\mathrm{SH})(\mathrm{cm})$}

Comparing the impact of Rock Phosphate (RP) levels, non significant differences were observed among RP level applied in terms of SH. There were significant differences among the impact of salinity levels, the highest $\mathrm{SH}$ was obtained in the seedlings treated with $\mathrm{S}_{1}$ in both seasons $(36.1$ and $47.9 \mathrm{~cm}$ for first and second season, respectively), whilst the lowest value was found in those treated with $S_{5}$ in both seasons (26.3 and $31.3 \mathrm{~cm}$ for first and second season, respectively) (Table $4)$.

As for the effect of inoculation with the symbiotic agent, it was found that the inoculated seedlings with VAM have exhibited the highest $\mathrm{SH}$ in both seasons (36.1 and $37.2 \mathrm{~cm}$ for first and second season, respectively) (Table 4).
Furthermore, the statistical analysis has also revealed the significant interaction between the impact of Rock-phosphate (RP) application and VAM inoculation and the triple interaction among RP application, salinity levels and VAM inoculation. The inoculated seedlings with VAM, fertilized with $\mathrm{RP}_{2}$ and applied with $\mathrm{S}_{2}$ displayed the highest value of $\mathrm{SH}$ in the first season, since it was $(49.9 \mathrm{~cm})$, yet in the second season the inoculated seedlings with VAM, unfertilized with $\mathrm{RP}_{2}$ and applied with $\mathrm{S}_{2}$ displayed the highest value of $\mathrm{SH}$, since it was $(49.8 \mathrm{~cm})$ (Table 4$)$.

\subsection{Shoot dry weight ( SDW) (g)}

It was found that the seedlings which fertilized with $\mathrm{RP}_{3}$ displayed the highest SDW in both growing seasons (3.1162 and 3.2813g for first and second season, respectively) (Table 5).

Table 4. Shoot height $(\mathrm{cm})$ of inoculated and uninoculated seedlings of Moringa oleifera Lam. with VAM, unfertilized and fertilized with RP under five levels of salinity

\begin{tabular}{|c|c|c|c|c|c|c|c|c|c|c|c|}
\hline \multicolumn{7}{|c|}{ First season } & \multicolumn{5}{|c|}{$\begin{array}{c}\text { Second season } \\
\end{array}$} \\
\hline \multirow{2}{*}{$\begin{array}{l}\text { Rock } \\
\text { phosphate } \\
\text { RP }\end{array}$} & \multirow{2}{*}{$\begin{array}{c}\text { Salinity } \\
\text { level } \\
(p p m)\end{array}$} & \multicolumn{2}{|c|}{$\begin{array}{c}\text { VAM } \\
\text { inoculation }\end{array}$} & \multirow[t]{2}{*}{$\mathbf{R P} * \mathbf{S}$} & \multirow[t]{2}{*}{$\mathbf{R P}$} & \multirow[t]{2}{*}{$\mathbf{S}$} & \multicolumn{2}{|c|}{$\begin{array}{c}\text { VAM } \\
\text { inoculation }\end{array}$} & \multirow[t]{2}{*}{$\mathbf{R P} * \mathbf{S}$} & \multirow[t]{2}{*}{$\mathbf{R P}$} & \multirow[t]{2}{*}{$\mathbf{S}$} \\
\hline & & $\mathbf{C}$ & VAM & & & & $\mathbf{C}$ & VAM & & & \\
\hline & $\mathrm{S}_{1}$ & 29.4 & 37.7 & 33.6 & & & 38.5 & 47.1 & 42.8 & & \\
\hline $\mathrm{Rp}_{1}$ & $\mathrm{~S}_{2}$ & 25.3 & 40.4 & 32.9 & & & 34.5 & 49.8 & 42.2 & & \\
\hline \multirow[t]{3}{*}{$0.0 \mathrm{~g}$} & $\mathrm{~S}_{3}$ & 23.6 & 38.6 & 31.1 & & & 32.9 & 47.9 & 40.4 & & \\
\hline & $\mathrm{S}_{4}$ & 23.6 & 35.8 & 29.7 & & & 32.9 & 45.2 & 39.1 & & \\
\hline & $\mathrm{S}_{5}$ & 13.0 & 30.3 & 21.7 & & & 22.3 & 39.8 & 31.1 & & \\
\hline \multirow[t]{2}{*}{$\mathrm{RP}_{1} * \mathrm{VAM}$} & & 23.0 & 36.6 & & 29.8 & & 32.2 & 46.0 & & 39.1 & \\
\hline & $\mathrm{S}_{1}$ & 31.0 & 37.6 & 34.3 & & & 37.9 & 37.2 & 37.6 & & \\
\hline $\mathrm{RP}_{2}$ & $\mathrm{~S}_{2}$ & 29.4 & 49.9 & 39.7 & & & 36.4 & 48.7 & 42.6 & & \\
\hline \multirow[t]{3}{*}{$1.0 \mathrm{~g}$} & $\mathrm{~S}_{3}$ & 24.4 & 41.7 & 33.1 & & & 31.8 & 40.5 & 36.2 & & \\
\hline & $\mathrm{S}_{4}$ & 22.8 & 33.5 & 28.2 & & & 30.3 & 32.3 & 31.3 & & \\
\hline & $\mathrm{S}_{5}$ & 0.0 & 27.7 & 13.9 & & & 0.0 & 26.6 & 13.8 & & \\
\hline \multirow[t]{2}{*}{$\mathrm{Rp}_{2} * \mathrm{VAM}$} & & 21.5 & 38.1 & & 29.8 & & 27.3 & 37.1 & & 32.3 & \\
\hline & $\mathrm{S}_{1}$ & 29.4 & 36.8 & 33.1 & & & 20.6 & 31.6 & 26.1 & & \\
\hline $\mathrm{Rp}_{3}$ & $\mathrm{~S}_{2}$ & 29.4 & 41.3 & 35.4 & & & 21.6 & 36.1 & 28.9 & & \\
\hline \multirow[t]{3}{*}{$2.0 \mathrm{~g}$} & $\mathrm{~S}_{3}$ & 26.7 & 27.6 & 27.2 & & & 19.3 & 22.6 & 21.0 & & \\
\hline & $\mathrm{S}_{4}$ & 31.1 & 34.0 & 32.6 & & & 23.1 & 28.9 & 26.0 & & \\
\hline & $\mathrm{S}_{5}$ & 0.0 & 28.5 & 14.3 & & & 0.0 & 23.5 & 11.8 & & \\
\hline \multirow[t]{3}{*}{$\mathrm{Rp}_{3} * \mathrm{VAM}$} & & 23.3 & 33.6 & & 28.5 & & 16.9 & 28.5 & & 22.7 & \\
\hline & $\mathrm{S}_{1}$ & 29.9 & 37.4 & & & 33.7 & 32.3 & 38.6 & & & 35.5 \\
\hline & $\mathrm{S}_{2}$ & 28.3 & 43.9 & & & 36.1 & 30.8 & 44.9 & & & 47.9 \\
\hline \multirow[t]{3}{*}{$\mathrm{S} * \mathrm{VAM}$} & $\mathrm{S}_{3}$ & 24.9 & 36.0 & & & 30.4 & 28.0 & 37.0 & & & 32.5 \\
\hline & $\mathrm{S}_{4}$ & 25.8 & 34.4 & & & 30.1 & 28.8 & 35.5 & & & 32.1 \\
\hline & $\mathrm{S}_{5}$ & 22.7 & 29.9 & & & 26.3 & 25.5 & 37.2 & & & 31.3 \\
\hline \multirow{3}{*}{$\begin{array}{l}\text { VAM } \\
\text { LSD at } \\
0.05\end{array}$} & & 22.6 & 36.1 & & & & 25.5 & 37.2 & & & \\
\hline & RP: ---- & & $S=2.10$ & & VA & $=2.46$ & \multirow{2}{*}{\multicolumn{3}{|c|}{$\begin{array}{l}\text { RP: } \\
\text { VAM }=2.46 \\
\text { RP*S*VAM= } 5.63\end{array}$}} & \multirow{2}{*}{\multicolumn{2}{|c|}{$\begin{array}{r}\mathrm{S}=2.33 \\
\mathrm{RP} * \mathrm{VAM}=4.41\end{array}$}} \\
\hline & \multicolumn{3}{|c|}{$\mathrm{RP} * \mathrm{VAM}=4.37$} & \multicolumn{3}{|c|}{$\mathrm{RP} * \mathrm{~S} * \mathrm{VAM}=5.23$} & & & & & \\
\hline
\end{tabular}


Table 5. shoot dry weight (g) of inoculated and uninoculated seedlings of Moringa oleifera Lam. with VAM, unfertilized and fertilized with RP under five levels of salinity

\begin{tabular}{|c|c|c|c|c|c|c|c|c|c|c|c|}
\hline \multicolumn{7}{|c|}{ First season } & \multicolumn{5}{|c|}{ Second season } \\
\hline \multirow{2}{*}{$\begin{array}{l}\text { Rock } \\
\text { phosphate } \\
\text { RP }\end{array}$} & \multirow{2}{*}{$\begin{array}{l}\text { Salinity } \\
\text { level } \\
(\text { ppm) }\end{array}$} & \multicolumn{2}{|c|}{$\begin{array}{c}\text { VAM } \\
\text { inoculation }\end{array}$} & \multirow[t]{2}{*}{$\mathbf{R P} * \mathbf{S}$} & \multirow[t]{2}{*}{$\mathbf{R P}$} & \multirow[t]{2}{*}{$\mathbf{S}$} & \multicolumn{2}{|c|}{$\begin{array}{c}\text { VAM } \\
\text { inoculation }\end{array}$} & \multirow[t]{2}{*}{$\mathbf{R P} * \mathbf{S}$} & \multirow[t]{2}{*}{ RP } & \multirow[t]{2}{*}{$\mathbf{S}$} \\
\hline & & C & VAM & & & & C & VAM & & & \\
\hline \multirow{5}{*}{$\begin{array}{l}\mathrm{Rp}_{1} \\
0.0 \mathrm{~g}\end{array}$} & $\mathrm{~S}_{1}$ & 1.831 & 2.871 & 2.351 & & & 1.607 & 3.528 & 2.5675 & & \\
\hline & $\mathrm{S}_{2}$ & 2.026 & 3.683 & 2.8545 & & & 1.779 & 4.528 & 3.1535 & & \\
\hline & $\mathrm{S}_{3}$ & 0.86 & 2.827 & 1.8435 & & & 0.755 & 3.475 & 2.115 & & \\
\hline & $\mathrm{S}_{4}$ & 0.791 & 2.643 & 1.717 & & & 0.695 & 3.249 & 1.972 & & \\
\hline & $\mathrm{S}_{5}$ & 0.413 & 1.679 & 1.046 & & & 0.363 & 2.064 & 1.2135 & & \\
\hline \multirow[t]{2}{*}{$\mathrm{RP}_{1} * \mathrm{VAM}$} & & 1.1842 & 2.7406 & & 1.9624 & & 1.0398 & 3.3688 & & 2.2043 & \\
\hline & $\mathrm{S}_{1}$ & 3.391 & 4.777 & 4.084 & & & 3.262 & 4.242 & 3.752 & & \\
\hline \multirow{4}{*}{$\begin{array}{l}\mathrm{RP}_{2} \\
1.0 \mathrm{~g}\end{array}$} & $\mathrm{~S}_{2}$ & 3.672 & 2.416 & 3.044 & & & 3.532 & 2.145 & 2.8385 & & \\
\hline & $\mathrm{S}_{3}$ & 1.585 & 2.015 & 1.8 & & & 1.525 & 1.789 & 1.657 & & \\
\hline & $\mathrm{S}_{4}$ & 1.202 & 0.749 & 0.9755 & & & 1.156 & 0.665 & 0.9105 & & \\
\hline & $\mathrm{S}_{5}$ & 0 & 1.657 & 0.8285 & & & 0 & 1.472 & 0.736 & & \\
\hline \multirow[t]{2}{*}{$\mathrm{Rp}_{2} * \mathrm{VAM}$} & & 1.97 & 2.3228 & & 2.1464 & & 1.895 & 2.0626 & & 1.9788 & \\
\hline & $\mathrm{S}_{1}$ & 3.272 & 2.687 & 2.9795 & & & 1.953 & 3.302 & 2.6275 & & \\
\hline $\mathrm{Rp}_{3}$ & $\mathrm{~S}_{2}$ & 3.095 & 6.695 & 4.895 & & & 2.789 & 8.229 & 5.509 & & \\
\hline \multirow[t]{3}{*}{$2.0 \mathrm{~g}$} & $\mathrm{~S}_{3}$ & 1.875 & 6.327 & 4.101 & & & 2.639 & 6.19 & 4.4145 & & \\
\hline & $\mathrm{S}_{4}$ & 2.239 & 3.705 & 2.972 & & & 1.599 & 4.554 & 3.0765 & & \\
\hline & $\mathrm{S}_{5}$ & 0 & 1.267 & 0.6335 & & & 0 & 1.558 & 0.779 & & \\
\hline \multirow[t]{3}{*}{ Rp3*VAM } & & 2.0962 & 4.1362 & & 3.1162 & & 1.796 & 4.7666 & & 3.2813 & \\
\hline & $\mathrm{S}_{1}$ & 1.6988 & 2.067 & & & 1.8829 & 1.3644 & 2.2144 & & & 1.7894 \\
\hline & $\mathrm{S}_{2}$ & 1.7196 & 2.3964 & & & 2.058 & 1.5856 & 2.7804 & & & 2.183 \\
\hline \multirow[t]{3}{*}{ S*VAM } & $\mathrm{S}_{3}$ & 0.864 & 2.2338 & & & 1.5489 & 0.9838 & 2.2908 & & & 1.6373 \\
\hline & $\mathrm{S}_{4}$ & 0.8464 & 1.4194 & & & 1.1329 & 0.69 & 1.6936 & & & 1.1918 \\
\hline & $\mathrm{S}_{5}$ & 0.0826 & 0.9206 & & & 0.5016 & 0.0726 & 1.0188 & & & 0.5457 \\
\hline \multirow{3}{*}{$\begin{array}{l}\text { VAM } \\
\text { LSD at } \\
0.05\end{array}$} & & 1.750 & 3.066 & & & & 1.577 & 3.399 & & & \\
\hline & $\begin{array}{l}\text { RP: } 0.02 \\
\text { VAM*S }\end{array}$ & 65 & $S=0.5462$ & & $\mathrm{VAM}=$ & $=1.2632$ & $\mathrm{RP}=0.0$ & 2451 & & $\mathrm{~S}=$ & 0.73254 \\
\hline & $\begin{array}{l}\mathrm{VAM} * \mathrm{~S}= \\
\mathrm{RP} * \mathrm{~S} * \mathrm{~V}\end{array}$ & $\begin{array}{l}0.1697 \\
M=3.233\end{array}$ & & & & & $\begin{array}{l}\mathrm{VAM}= \\
\mathrm{RP} * \mathrm{~S} * \mathrm{~V}\end{array}$ & $\begin{array}{l}1.76214 \\
\mathrm{M}=4.463\end{array}$ & & 25 & $=0.56841$ \\
\hline
\end{tabular}

The inoculation with VAM has also brought about the highest SDW in both seasons (3.066 and 3.3993g), respectively, while uninoculated seedlings displayed the lowest value of SDW, since it was (1.750 and $1.576 \mathrm{~g}$ for first and second season, respectively) (Table 5). Furthermore, the significant interaction between salinity level and VAM inoculation has revealed that the seedlings applied with $S_{2}$ and inoculated with VAM fungus induced the highest SDW (2.396 and 2.7804g for first and second season, respectively), followed by inoculated seedlings with VAM and applied with $\mathrm{S}_{3}$ level (Table 5).

As for the significant triple interaction of the factors studied, it was found that the seedlings inoculated with VAM which applied with $\mathrm{RP}_{3}$ amended with $\mathrm{S}_{2}$ displayed the highest SDW in both seasons (6.695 and $8.229 \mathrm{~g}$ for first and second season, respectively) (Table $5)$.

\subsection{Root dry weight (RDW) (g)}

There were significant effects of the salinity level. However, seedlings amended with $\mathrm{S}_{3}$ displayed the highest RDW in both seasons (6.202 and 6.44 for first and second season, respectively). (Table 6).

As for the impact of inoculation of mycorrhizal fungus, there were significant differences among uninoculated seedlings (control) and inoculated ones with VAM, since the inoculated seedlings displayed the highest value of RDW in the both seasons, respectively, (7.867 and $8.168 \mathrm{~g}$ for first and second season, respectively) (Table 6).

Upon the triple interaction, there was a significant interaction among the three studied factors. However, the highest TDW was obtained in the inoculated seedlings which applied with $\mathrm{Rp}_{3}$ and amended with $\mathrm{S}_{2}$ in both seasons (19.66 and 20.42g for first and second season, respectively). (Table 6). 
Table 6. Root dry weight (g) of inoculated and uninoculated seedlings of Moringa oleifera Lam. with VAM, unfertilized and fertilized with RP under five levels of salinity

\begin{tabular}{|c|c|c|c|c|c|c|c|c|c|c|c|}
\hline \multicolumn{7}{|c|}{ First season } & \multicolumn{5}{|c|}{ Second season } \\
\hline \multirow{2}{*}{$\begin{array}{l}\text { Rock } \\
\text { phosphate } \\
\text { RP }\end{array}$} & \multirow{2}{*}{$\begin{array}{c}\text { Salinity } \\
\text { level } \\
\text { (ppm) }\end{array}$} & \multicolumn{2}{|c|}{$\begin{array}{c}\text { VAM } \\
\text { inoculation } \\
\end{array}$} & \multirow[t]{2}{*}{$\mathbf{R P} * \mathbf{S}$} & \multirow[t]{2}{*}{$\mathbf{R P}$} & \multirow[t]{2}{*}{$\mathbf{S}$} & \multicolumn{2}{|c|}{$\begin{array}{c}\text { VAM } \\
\text { inoculation }\end{array}$} & \multirow[t]{2}{*}{$\mathbf{R P} * \mathbf{S}$} & \multirow[t]{2}{*}{$\mathbf{R P}$} & \multirow[t]{2}{*}{$\mathbf{S}$} \\
\hline & & $\mathbf{C}$ & VAM & & & & $\mathbf{C}$ & VAM & & & \\
\hline & $\mathrm{S}_{1}$ & 9.91 & 6.38 & 8.145 & & & 10.29 & 6.62 & 8.455 & & \\
\hline $\mathrm{Rp}_{1}$ & $\mathrm{~S}_{2}$ & 4.86 & 15.19 & 10.025 & & & 5.05 & 15.77 & 10.41 & & \\
\hline \multirow[t]{3}{*}{$0.0 \mathrm{~g}$} & $\mathrm{~S}_{3}$ & 13.85 & 3.42 & 8.635 & & & 14.38 & 3.55 & 8.965 & & \\
\hline & $\mathrm{S}_{4}$ & 3.41 & 12.64 & 8.025 & & & 3.54 & 13.13 & 8.335 & & \\
\hline & $\mathrm{S}_{5}$ & 12.45 & 3.75 & 8.1 & & & 12.93 & 3.9 & 8.415 & & \\
\hline \multirow[t]{2}{*}{$\mathrm{RP}_{1} * \mathrm{VAM}$} & & 8.896 & 8.276 & & 8.586 & & 9.238 & 8.594 & & 8.916 & \\
\hline & $S_{1}$ & 9.03 & 4.34 & 6.685 & & & 9.37 & 4.51 & 6.94 & & \\
\hline $\mathrm{RP}_{2}$ & $\mathrm{~S}_{2}$ & 4.45 & 8.66 & 6.555 & & & 4.62 & 8.99 & 6.805 & & \\
\hline \multirow[t]{3}{*}{$1.0 \mathrm{~g}$} & $\mathrm{~S}_{3}$ & 12.3 & 7.14 & 9.72 & & & 12.77 & 7.42 & 10.095 & & \\
\hline & $\mathrm{S}_{4}$ & 3.31 & 2.4 & 2.855 & & & 3.44 & 2.49 & 2.965 & & \\
\hline & $\mathrm{S}_{5}$ & 0 & 2.3 & 1.15 & & & 0 & 2.38 & 1.19 & & \\
\hline \multirow[t]{2}{*}{$\mathrm{Rp}_{2} * \mathrm{VAM}$} & & 5.818 & 4.968 & & 5.393 & & 6.04 & 5.158 & & 5.599 & \\
\hline & $\mathrm{S}_{1}$ & 11.27 & 8.77 & 10.02 & & & 11.7 & 9.1 & 10.4 & & \\
\hline $\mathrm{Rp}_{3}$ & $\mathrm{~S}_{2}$ & 6.51 & 19.66 & 13.085 & & & 6.76 & 20.42 & 13.59 & & \\
\hline \multirow[t]{3}{*}{$2.0 \mathrm{~g}$} & $\mathrm{~S}_{3}$ & 12.51 & 12.8 & 12.655 & & & 12.99 & 13.29 & 13.14 & & \\
\hline & $\mathrm{S}_{4}$ & 2.27 & 5.36 & 3.815 & & & 2.36 & 5.56 & 3.96 & & \\
\hline & $\mathrm{S}_{5}$ & 0 & 5.2 & 2.6 & & & 0 & 5.4 & 2.7 & & \\
\hline \multirow[t]{3}{*}{$\mathrm{Rp}_{3} * \mathrm{VAM}$} & & 6.512 & $\begin{array}{c}10.35 \\
8\end{array}$ & & 8.435 & & 6.762 & 10.754 & & 8.758 & \\
\hline & $\mathrm{S}_{1}$ & 6.042 & 3.898 & & & 4.97 & 6.272 & 4.046 & & & 5.159 \\
\hline & $\mathrm{S}_{2}$ & 3.164 & 8.702 & & & 5.933 & 3.286 & 9.036 & & & 6.161 \\
\hline \multirow[t]{3}{*}{ S*VAM } & $\mathrm{S}_{3}$ & 7.732 & 4.672 & & & 6.202 & 8.028 & 4.852 & & & 6.44 \\
\hline & $\mathrm{S}_{4}$ & 1.798 & 4.08 & & & 2.939 & 1.868 & 4.236 & & & 3.052 \\
\hline & $\mathrm{S}_{5}$ & 2.49 & 2.25 & & & 2.37 & 2.586 & 2.336 & & & 2.461 \\
\hline VAM & & & 7.867 & & & & & & & & \\
\hline \multirow[b]{2}{*}{ LSD at 0.05} & & 7.0753 & 3 & & \multirow{2}{*}{\multicolumn{2}{|c|}{$\mathrm{VAM}=0.000315$}} & 7.3467 & 8.1687 & & & \\
\hline & $\begin{array}{l}R P=-- \\
R P * S *\end{array}$ & $\mathrm{AM}=3$. & $\begin{array}{l}S=0.02563 \\
452\end{array}$ & & & & $\mathrm{RP}=----$ & $\begin{array}{r}S=0.0 \\
R P * S \\
\end{array}$ & $\begin{array}{l}415 \\
\text { VAM }=\end{array}$ & $\begin{array}{l}\mathrm{VAM}=0 \\
3.964\end{array}$ & 00036 \\
\hline
\end{tabular}

\subsection{Total dry weight (TDW) (g)}

Seedlings treated with $\mathrm{S}_{2}$ displayed the highest TDW in both seasons (7.991 and 8.344g for first and second season, respectively), while the seedlings which applied with $\mathrm{S}_{5}$ recorded in both seasons $(2.872$ and $3.007 \mathrm{~g}$ for first and second season, respectively), (Table 7).

As for the effect of inoculation with symbiotic agent, there were significant differences among uninoculated seedlings (control) and inoculated ones with symbiotic agent under study. It was found that the inoculated seedlings had the highest TDW in both seasons (10.934 and $11.568 \mathrm{~g}$ ), respectively (Table 7).

Finally, there was a significant interaction among the three factors studied. It can be observed that the highest TDW was obtained in the inoculated seedlings, applied with $\mathrm{Rp}_{3}$ and amended with $\mathrm{S}_{3}$ in both seasons (26.335 and $28.649 \mathrm{~g}$ for first and second season, respectively), (Table 7).

\subsection{Shoot/ root ratio (SRR)}

Application of RP the seedlings which treated with $\mathrm{RP}_{3}$ induced that the highest SRR in both seasons, $(0.522$ and 0.375 for first and second season, respectively), (Table 8).

Upon the significant interaction between RP application and VAM inoculation it was found that the seedlings inoculated with VAM and treated with level $\mathrm{RP}_{2}$ displayed the highest SRR (0.468) in the first season, yet in the second season the inoculated seedlings with mycorrhiza and treated with $\mathrm{RP}_{3}$ displayed the highest SRR, since it was (0.443). (Table 8). 
Considering the significant triple interaction among the studied factors, the inoculated seedlings which were amended with RP2 and untreated with salt have displayed the highest SRR (1.101, 0.941 for first and second season, respectively) (Table 8).

\section{Chemical analysis:}

\subsection{Chlorophyll a(Chl a) and Chlorophyll b (Chl b) (mg/100g).}

Chlorophyll a of Moringa oleifera was affected by salinity (Table 9). $\mathrm{Na} \mathrm{Cl}$ treatments caused a decrease in chlorophyll a and chlorophyll $\mathrm{b}$ content in both seasons, since it was $67.49 \mathrm{mg} / 100 \mathrm{~g}$ at $128.24 \mathrm{mM}$ and $54.81 \mathrm{mg} / 100$ at $171.1 \mathrm{mM}$ in the first season for chlorophyll a and as $72.25 \mathrm{mg} / 100 \mathrm{~g}$ at $128.24 \mathrm{mM}$ and $58.79 \mathrm{mg} / 100$ at $171.1 \mathrm{mM}$ in the second season. Similar responses in chlorophyll b were observed (Table 10). According to the significant interaction between salinity and RP treatments, the addition of $\mathrm{RP}_{3}+\mathrm{S}_{1}$ gave the highest chlorophyll a and $(75.88$ and $81.24 \mathrm{mg} / 100 \mathrm{~g}$ in the first and second season, respectively) and chlorophyll b (112.95 and $126.69 \mathrm{mg} / 100 \mathrm{~g}$ in the first and second season, respectively). (Tables 9 and 10). Under salinity stress, photosynthetic Pigments were reduced due to accumulation of higher concentrations of $\mathrm{Na}+$ in chloroplasts. It seems that proline may enhance the production of photosynthetic pigments of the tolerant $M$. oleifera under salt stress.

As for the impact of inoculation with VAM, the inoculated seedlings with VAM has induced the highest value in chlorophyll a (73.56 and $79.44 \mathrm{mg} / 100 \mathrm{~g}$ for first and second season, respectively) and chlorophyll $b$ (53.86and $64.66 \mathrm{mg} / 100 \mathrm{~g}$ for first and second season, respectively) (Tables 9 and 10).

Table 7. Total dry weight (g) of inoculated and uninoculated seedlings of Moringa oleifera Lam. with VAM, unfertilized and fertilized with RP under five levels of salinity

\begin{tabular}{|c|c|c|c|c|c|c|c|c|c|c|c|}
\hline \multicolumn{7}{|c|}{ First season } & \multicolumn{5}{|c|}{ Second season } \\
\hline \multirow{2}{*}{$\begin{array}{l}\text { Rock } \\
\text { phosphate } \\
\text { RP } \\
\end{array}$} & \multirow{2}{*}{$\begin{array}{c}\text { Salinity } \\
\text { level } \\
(\mathbf{p p m})\end{array}$} & \multicolumn{2}{|c|}{$\begin{array}{c}\text { VAM } \\
\text { inoculation }\end{array}$} & \multirow[t]{2}{*}{$\mathbf{R P} * \mathbf{S}$} & \multirow[t]{2}{*}{$\mathbf{R P}$} & \multirow[t]{2}{*}{$\mathbf{S}$} & \multicolumn{2}{|c|}{$\begin{array}{c}\text { VAM } \\
\text { inoculation }\end{array}$} & \multirow[t]{2}{*}{$\mathbf{R P} * \mathbf{S}$} & \multirow[t]{2}{*}{$\mathbf{R P}$} & \multirow[t]{2}{*}{$\mathbf{S}$} \\
\hline & & C & VAM & & & & $\mathbf{C}$ & VAM & & & \\
\hline & $\mathrm{S}_{1}$ & 11.741 & 9.251 & 10.496 & & & 11.897 & 10.148 & 11.023 & & \\
\hline $\mathrm{Rp}_{1}$ & $\mathrm{~S}_{2}$ & 6.886 & 18.873 & 12.880 & & & 6.829 & 19.298 & 13.264 & & \\
\hline \multirow[t]{3}{*}{$0.0 \mathrm{~g}$} & $\mathrm{~S}_{3}$ & 14.710 & 6.247 & 10.479 & & & 15.135 & 7.025 & 11.080 & & \\
\hline & $\mathrm{S}_{4}$ & 4.201 & 15.283 & 9.742 & & & 4.235 & 16.379 & 10.307 & & \\
\hline & $\mathrm{S}_{5}$ & 12.863 & 5.429 & 9.146 & & & 13.293 & 5.964 & 9.629 & & \\
\hline \multirow[t]{2}{*}{$\mathrm{RP}_{1} * \mathrm{VAM}$} & & 10.080 & 11.017 & & 10.548 & & 10.278 & 11.963 & & 11.120 & \\
\hline & $\mathrm{S}_{1}$ & 12.421 & 9.117 & 10.769 & & & 12.632 & 8.752 & 10.692 & & \\
\hline $\mathrm{RP}_{2}$ & $\mathrm{~S}_{2}$ & 8.122 & 11.076 & 9.599 & & & 8.152 & 11.135 & 9.644 & & \\
\hline \multirow[t]{3}{*}{$1.0 \mathrm{~g}$} & $\mathrm{~S}_{3}$ & 13.885 & 9.155 & 11.520 & & & 14.295 & 9.209 & 11.752 & & \\
\hline & $\mathrm{S}_{4}$ & 1.202 & 3.049 & 2.126 & & & 1.156 & 3.045 & 2.101 & & \\
\hline & $\mathrm{S}_{5}$ & 0.000 & 3.957 & 1.979 & & & 0.000 & 3.852 & 1.926 & & \\
\hline \multirow[t]{2}{*}{$\mathrm{Rp}_{2} * \mathrm{VAM}$} & & 7.788 & 7.291 & & 7.539 & & 7.935 & 7.221 & & 7.578 & \\
\hline & $\mathrm{S}_{1}$ & 3.272 & 2.687 & 2.980 & & & 1.953 & 3.302 & 2.628 & & \\
\hline $\mathrm{Rp}_{3}$ & $\mathrm{~S}_{2}$ & 14.542 & 11.457 & 13.000 & & & 13.653 & 12.402 & 13.028 & & \\
\hline \multirow[t]{3}{*}{$2.0 \mathrm{~g}$} & $\mathrm{~S}_{3}$ & 14.385 & 26.335 & 16.756 & & & 15.629 & 28.649 & 17.555 & & \\
\hline & $\mathrm{S}_{4}$ & 4.509 & 9.065 & 6.787 & & & 3.959 & 10.114 & 7.037 & & \\
\hline & $\mathrm{S}_{5}$ & 0.000 & 6.467 & 3.234 & & & 0.000 & 6.958 & 3.479 & & \\
\hline \multirow[t]{3}{*}{$\mathrm{Rp}_{3} * \mathrm{VAM}$} & & 8.608 & 14.494 & & 11.551 & & 8.558 & 15.521 & & 12.039 & \\
\hline & $\mathrm{S}_{1}$ & 7.741 & 5.965 & & & 6.853 & 7.636 & 6.260 & & & 6.948 \\
\hline & $\mathrm{S}_{2}$ & 4.884 & 11.098 & & & 7.991 & 4.872 & 11.816 & & & 8.344 \\
\hline \multirow[t]{3}{*}{ S*VAM } & $\mathrm{S}_{3}$ & 8.596 & 6.906 & & & 7.751 & 9.012 & 7.143 & & & 8.077 \\
\hline & $\mathrm{S}_{4}$ & 2.644 & 5.499 & & & 4.072 & 2.558 & 5.930 & & & 4.244 \\
\hline & $\mathrm{S}_{5}$ & 2.573 & 3.171 & & & 2.872 & 2.659 & 3.355 & & & 3.007 \\
\hline VAM & & 8.825 & 10.934 & & & & 8.924 & 11.568 & & & \\
\hline LSD at & \multirow{2}{*}{\multicolumn{2}{|c|}{$\begin{array}{l}\text { RP: ------ } \\
\text { RP*S*VAM= } 4.3522\end{array}$}} & \multirow{2}{*}{\multicolumn{2}{|c|}{$\mathrm{S}=0.0 .321$}} & \multirow{2}{*}{\multicolumn{2}{|c|}{$\mathrm{VAM}=1.457$}} & \multirow{2}{*}{\multicolumn{2}{|c|}{$\begin{array}{l}\mathrm{RP}=----- \\
\mathrm{VAM}=1.814\end{array}$}} & & \multirow{2}{*}{\multicolumn{2}{|c|}{$\begin{aligned} & S=0.73254 \\
M= & 4.7514\end{aligned}$}} \\
\hline 0.05 & & & & & & & & & $\mathrm{RP} * \mathrm{~S} * \mathrm{~V}$ & & \\
\hline
\end{tabular}


Table 8. Shoot root ratio of inoculated and uninoculated seedlings of Moringa oleifera Lam. with VAM, unfertilized and fertilized with RP under five levels of salinity

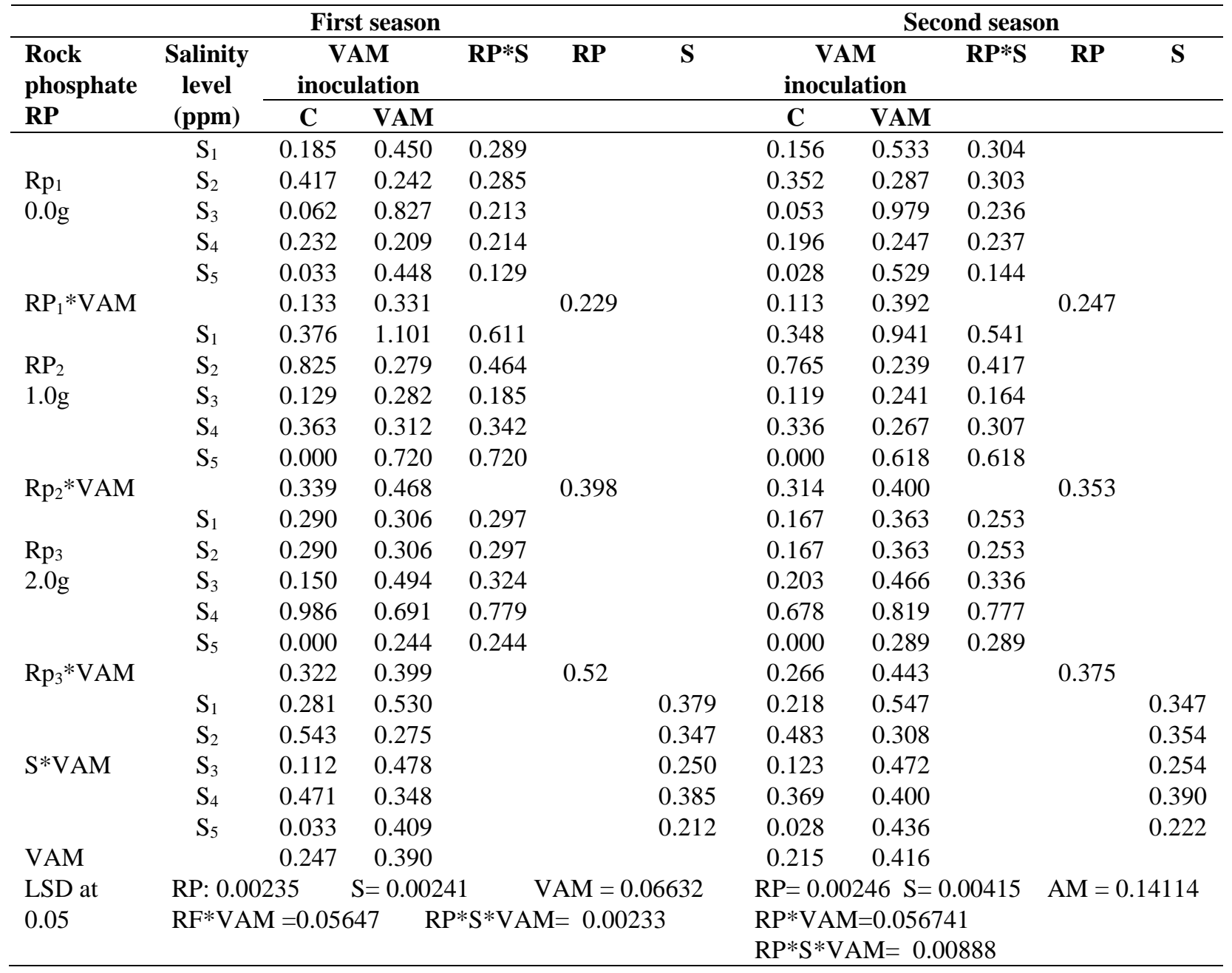

Table 9. Cholorophyll a $(\mathrm{mg} / 100 \mathrm{~g})$ of inoculated and uninoculated seedlings of Moringa oleifera Lam. with VAM, unfertilized and fertilized with RP under five levels of salinity

\begin{tabular}{|c|c|c|c|c|c|c|c|c|c|c|c|}
\hline \multicolumn{7}{|c|}{ First season } & \multicolumn{5}{|c|}{ Second season } \\
\hline \multirow{2}{*}{$\begin{array}{l}\text { Rock } \\
\text { phosphate } \\
\text { RP }\end{array}$} & \multirow{2}{*}{$\begin{array}{c}\text { Salinity } \\
\text { level } \\
\text { (ppm) }\end{array}$} & \multicolumn{2}{|c|}{$\begin{array}{c}\text { VAM } \\
\text { inoculation }\end{array}$} & \multirow[t]{2}{*}{$\mathbf{R P} * \mathbf{S}$} & \multirow[t]{2}{*}{$\mathbf{R P}$} & \multirow[t]{2}{*}{$\mathbf{S}$} & \multicolumn{2}{|c|}{$\begin{array}{c}\text { VAM } \\
\text { inoculation }\end{array}$} & \multirow[t]{2}{*}{$\mathbf{R P} * \mathbf{S}$} & \multirow[t]{2}{*}{$\mathbf{R P}$} & \multirow[t]{2}{*}{$\mathbf{S}$} \\
\hline & & $\mathbf{C}$ & VAM & & & & $\mathbf{C}$ & VAM & & & \\
\hline & S1 & 70.36 & 78.2 & 74.28 & \multirow{11}{*}{68.64} & & 74.58 & 84.46 & 79.52 & \multirow{11}{*}{73.49} & \\
\hline $\mathrm{Rp}_{1}$ & $\mathrm{~S} 2$ & 65.37 & 74.57 & 69.97 & & & 69.29 & 80.54 & 74.915 & & \\
\hline \multirow[t]{3}{*}{$0.0 \mathrm{~g}$} & S3 & 64.82 & 73.02 & 68.92 & & & 68.71 & 78.86 & 73.785 & & \\
\hline & S4 & 62.29 & 70.49 & 66.39 & & & 66.03 & 76.13 & 71.08 & & \\
\hline & S5 & 59.56 & 67.76 & 63.66 & & & 63.13 & 73.18 & 68.155 & & \\
\hline \multirow[t]{2}{*}{$\mathrm{RP}_{1} * \mathrm{VAM}$} & & 64.48 & 72.81 & & & & 68.35 & 78.63 & & & \\
\hline & S1 & 68.34 & 76.54 & 72.44 & & & 72.44 & 82.66 & 77.55 & & \\
\hline $\mathrm{RP}_{2}$ & S2 & 66.63 & 72.83 & 69.73 & & & 70.63 & 78.66 & 74.645 & & \\
\hline \multirow[t]{3}{*}{$1.0 \mathrm{~g}$} & S3 & 66.1 & 72.3 & 69.2 & & & 70.07 & 78.08 & 74.075 & & \\
\hline & S4 & 63.47 & 68.67 & 66.07 & & & 67.28 & 74.16 & 70.72 & & \\
\hline & S5 & 60.91 & 69.11 & 65.01 & & & 64.56 & 74.64 & 69.6 & & \\
\hline
\end{tabular}


Cont.Table 9. Cholorophyll a (mg/ 100g) of inoculated and uninoculated seedlings of Moringa oleifera Lam. with VAM, unfertilized and fertilized with RP under five levels of salinity

\begin{tabular}{|c|c|c|c|c|c|c|c|c|c|c|c|}
\hline \multicolumn{7}{|c|}{ First season } & \multicolumn{5}{|c|}{ Second season } \\
\hline \multirow{2}{*}{$\begin{array}{l}\text { Rock } \\
\text { phosphate } \\
\text { RP }\end{array}$} & \multirow{2}{*}{$\begin{array}{c}\text { Salinity } \\
\text { level } \\
\text { (ppm) }\end{array}$} & \multicolumn{2}{|c|}{$\begin{array}{c}\text { VAM } \\
\text { inoculation }\end{array}$} & \multirow[t]{2}{*}{$\mathbf{R P} * \mathbf{S}$} & \multirow[t]{2}{*}{$\mathbf{R P}$} & \multirow[t]{2}{*}{$\mathbf{S}$} & \multicolumn{2}{|c|}{$\begin{array}{c}\text { VAM } \\
\text { inoculation }\end{array}$} & \multirow[t]{2}{*}{$\mathbf{R P} * \mathbf{S}$} & \multirow[t]{2}{*}{$\mathbf{R P}$} & \multirow[t]{2}{*}{$\mathbf{S}$} \\
\hline & & C & VAM & & & & C & VAM & & & \\
\hline \multirow[t]{2}{*}{$\mathrm{Rp}_{2} * \mathrm{VAM}$} & & 65.09 & 71.89 & & 68.49 & & 69 & 77.64 & & 73.32 & \\
\hline & S1 & 71.78 & 79.98 & 75.88 & & & 76.09 & 86.38 & 81.235 & & \\
\hline $\mathrm{Rp}_{3}$ & $\mathrm{~S} 2$ & 69.22 & 77.42 & 73.32 & & & 73.37 & 83.61 & 78.49 & & \\
\hline \multirow[t]{3}{*}{$2.0 \mathrm{~g}$} & S3 & 68.72 & 76.92 & 72.82 & & & 72.84 & 83.07 & 77.955 & & \\
\hline & S4 & 65.9 & 74.1 & 70 & & & 69.85 & 80.03 & 74.94 & & \\
\hline & S5 & 0 & 71.51 & 35.76 & & & 0 & 77.23 & 38.615 & & \\
\hline \multirow[t]{3}{*}{$\mathrm{Rp}_{3} * \mathrm{VAM}$} & & 55.124 & 75.99 & & 65.557 & & 58.43 & 82.06 & & 70.245 & \\
\hline & S1 & 70.16 & 78.24 & & & 74.2 & 74.37 & 84.5 & & & 79.44 \\
\hline & $\mathrm{S} 2$ & 67.07 & 74.94 & & & 71.01 & 71.1 & 80.94 & & & 76.02 \\
\hline \multirow[t]{3}{*}{ S*VAM } & S3 & 66.55 & 74.08 & & & 70.31 & 70.54 & 80 & & & 75.27 \\
\hline & S4 & 63.89 & 71.09 & & & 67.49 & 67.72 & 76.77 & & & 72.25 \\
\hline & S5 & 40.16 & 69.46 & & & 54.81 & 42.56 & 75.02 & & & 58.79 \\
\hline VAM & & 61.56 & 73.56 & & & & 65.26 & 79.44 & & & \\
\hline LSD at & & $\mathrm{S}=3$ & 026 & \multirow{2}{*}{\multicolumn{3}{|c|}{$\begin{array}{c}\mathrm{VAM}=4.523 \\
\mathrm{RP} * \mathrm{~S} * \mathrm{VAM}=4.0025\end{array}$}} & \multirow{2}{*}{\multicolumn{3}{|c|}{$\begin{array}{l}R P=--S=3.0798 \\
R P * S-1511\end{array}$}} & VAM & $=4.555$ \\
\hline 0.05 & \multicolumn{3}{|c|}{$\mathrm{RP}^{*} \mathrm{~S} *=1.521$} & & & & & 1.5411 & $\mathrm{RP} * \mathrm{~S} * \mathrm{~V}$ & $\mathrm{AM}=4$. & 0.369 \\
\hline
\end{tabular}

Table 10. Cholorophyll b $(\mathrm{mg} / \mathbf{1 0 0 g})$ of inoculated and uninoculated seedlings of Moringa oleifera Lam. with VAM, unfertilized and fertilized with RP under five levels of salinity

\begin{tabular}{|c|c|c|c|c|c|c|c|c|c|c|c|}
\hline \multicolumn{7}{|c|}{ First season } & \multicolumn{5}{|c|}{ Second season } \\
\hline \multirow{2}{*}{$\begin{array}{l}\text { Rock } \\
\text { phosphate } \\
\text { RP }\end{array}$} & \multirow{2}{*}{$\begin{array}{c}\text { Salinity } \\
\text { level } \\
(\mathrm{ppm})\end{array}$} & \multicolumn{2}{|c|}{$\begin{array}{c}\text { VAM } \\
\text { inoculation }\end{array}$} & \multirow[t]{2}{*}{$\mathbf{R P} * \mathbf{S}$} & \multirow[t]{2}{*}{$\mathbf{R P}$} & \multirow[t]{2}{*}{$\mathbf{S}$} & \multicolumn{2}{|c|}{$\begin{array}{c}\text { VAM } \\
\text { inoculation }\end{array}$} & \multirow[t]{2}{*}{$\mathbf{R P} * \mathbf{S}$} & \multirow[t]{2}{*}{$\mathbf{R P}$} & \multirow[t]{2}{*}{$\mathbf{S}$} \\
\hline & & C & VAM & & & & C & VAM & & & \\
\hline & S1 & 33.02 & 110.36 & 71.69 & & & 33.02 & 34.67 & 33.85 & & \\
\hline Rp1 & S2 & 44.35 & 51.44 & 47.90 & & & 44.35 & 46.57 & 45.46 & & \\
\hline \multirow[t]{3}{*}{$0.0 \mathrm{~g}$} & S3 & 36.45 & 43.36 & 39.91 & & & 36.45 & 38.27 & 37.36 & & \\
\hline & S4 & 36.77 & 36.52 & 36.65 & & & 36.77 & 38.61 & 37.69 & & \\
\hline & S5 & 21.54 & 35.41 & 28.48 & & & 21.54 & 22.62 & 22.08 & & \\
\hline \multirow[t]{2}{*}{$0.0 * \mathrm{VAM}$} & & 34.43 & 55.42 & & 44.92 & & 34.43 & 36.15 & & 35.29 & \\
\hline & S1 & 34.92 & 107.36 & 71.14 & & & 34.92 & 36.67 & 35.80 & & \\
\hline RP2 & S2 & 44.65 & 49.56 & 47.11 & & & 44.65 & 46.88 & 45.77 & & \\
\hline \multirow[t]{3}{*}{$1.0 \mathrm{~g}$} & S3 & 38.45 & 37.36 & 37.91 & & & 38.45 & 40.37 & 39.41 & & \\
\hline & S4 & 39.77 & 31.66 & 35.72 & & & 39.77 & 41.76 & 40.77 & & \\
\hline & S5 & 24.54 & 26.21 & 25.38 & & & 24.54 & 25.77 & 25.16 & & \\
\hline \multirow[t]{2}{*}{ Rp2*VAM } & & 36.47 & 50.43 & & 43.45 & & 36.47 & 38.29 & & 37.38 & \\
\hline & S1 & 78.92 & 146.97 & 112.95 & & & 76.04 & 177.33 & 126.69 & & \\
\hline Rp3 & S2 & 48.65 & 54.06 & 51.36 & & & 46.13 & 59.33 & 52.73 & & \\
\hline \multirow[t]{3}{*}{$2.0 \mathrm{~g}$} & S3 & 48.45 & 37.00 & 42.73 & & & 46.78 & 42.04 & 44.41 & & \\
\hline & S4 & 39.77 & 22.11 & 30.94 & & & 35.66 & 28.60 & 32.13 & & \\
\hline & S5 & 0.00 & 18.56 & 9.28 & & & 0.00 & 20.45 & 10.23 & & \\
\hline \multirow[t]{3}{*}{ Rp3*VAM } & & 43.16 & 55.74 & & 49.45 & & 40.92 & 65.55 & & 53.24 & \\
\hline & S1 & 48.95 & 121.56 & & & 85.26 & 47.99 & 82.89 & & & 65.44 \\
\hline & $\mathrm{S} 2$ & 45.88 & 51.69 & & & 48.79 & 45.04 & 50.93 & & & 47.99 \\
\hline \multirow[t]{3}{*}{ S*VAM } & S3 & 41.12 & 39.24 & & & 40.18 & 40.56 & 40.23 & & & 40.39 \\
\hline & S4 & 38.77 & 30.10 & & & 34.43 & 37.40 & 36.32 & & & 36.86 \\
\hline & S5 & 15.36 & 26.73 & & & 21.04 & 15.36 & 22.95 & & & 19.15 \\
\hline VAM & & 38.02 & 53.86 & & & & 37.27 & 46.66 & & & \\
\hline LSD at & \multirow{2}{*}{\multicolumn{2}{|c|}{$\begin{array}{l}\text { RP: ----- } \\
\text { RP*S* }=1.521\end{array}$}} & \multirow{2}{*}{\multicolumn{4}{|c|}{$\mathrm{RP} * \mathrm{~S} * \mathrm{VAM}=4.0025$}} & $\mathrm{RP}=----$ & \multirow{2}{*}{$\begin{array}{r}S=3 \\
5411\end{array}$} & 0798 & \multirow{2}{*}{\multicolumn{2}{|c|}{$\begin{array}{r}\mathrm{VAM}=4.847 \\
\mathrm{AM}=4.0 .369\end{array}$}} \\
\hline 0.05 & & & & & & & $\mathrm{RP} * \mathrm{~S}=1$ & & $\mathrm{RP} * \mathrm{~S} *$ & & \\
\hline
\end{tabular}




\subsection{Proline content (g/10u0g).}

There is a significant increase in proline accumulation in both seasons with the highest rate of increase in salinity. Proline is increased significantly with the increasing in the concentration of salinity at the fifth level of $\mathrm{NaCl}\left(\mathrm{S}_{5}\right)$ in both seasons (13.54 and $15.90 \mathrm{~g} / 100 \mathrm{~g}$, for first and second season, respectively) (Tables, 11).

As for the effect of inoculation with VAM, the inoculated seedlings with VAM induced the highest value in Proline content in the first and second seasons (11.18 and $13.73 \mathrm{~g} / 100 \mathrm{~g}$, for first and second season, respectively) (Tables, 11).

\subsection{Mineral contents (N, P, K and Na) of leaves.}

Significant depressions were obtained in potassium concentration as a result of growing seedlings of Moringa oliefera under salinity condition in both seasons (Table 13), while nitrogen increased significantly only with the third level of salinity $S_{3}$, Phosphorous concentration increased was significantly under the fourth level of salinity $\mathrm{S}_{4}$ (Tables 11 and 12). Regardless, the effect of salinity and RP application, the inoculated seedlings with VAM fungus displayed the highest values in $\mathrm{N}$ (2.95 and 3.07\% for first and second season, respectively), $\mathrm{P}(0.52$ and $0.50 \%$ for first and second season, respectively) and $\mathrm{K}$ content (\%) (1.97 and $1.85 \%$ for first and second season, respectively, (Tables, 11, 12 and 13). Furthermore, the significant interaction between RP application and symbiosis agent has manifested the highest values of N (3.42 and 3.86\% for first and second season, respectively), K (2.17 and $2.04 \%$ for first and second season, respectively) and $\mathrm{P}$ (0.70and $0.69 \%$ for first and second season, respectively). (Tables, 11, 12 and 13).

Table 11. Proline content (g/ 100g) of inoculated and uninoculated seedlings of Moringa oleifera Lam. with VAM, unfertilized and fertilized with RP under five levels of salinity

\begin{tabular}{|c|c|c|c|c|c|c|c|c|c|c|c|}
\hline \multirow{3}{*}{$\begin{array}{l}\text { Rock } \\
\text { phosphate } \\
\text { RP } \\
\end{array}$} & \multirow{3}{*}{$\begin{array}{c}\text { Salinity } \\
\text { level } \\
\text { (ppm) }\end{array}$} & \multicolumn{3}{|c|}{ First season } & \multirow{3}{*}{$\mathbf{R P}$} & \multirow{3}{*}{$\mathbf{S}$} & \multicolumn{5}{|c|}{ Second season } \\
\hline & & \multicolumn{2}{|c|}{$\begin{array}{c}\text { VAM } \\
\text { inoculation }\end{array}$} & \multirow[t]{2}{*}{$\mathbf{R P} * \mathbf{S}$} & & & \multicolumn{2}{|c|}{$\begin{array}{c}\text { VAM } \\
\text { inoculation }\end{array}$} & \multirow[t]{2}{*}{$\mathbf{R P} * \mathbf{S}$} & \multirow[t]{2}{*}{$\mathbf{R P}$} & \multirow[t]{2}{*}{$\mathbf{S}$} \\
\hline & & $\mathrm{C}$ & VAM & & & & $\mathbf{C}$ & VAM & & & \\
\hline & S1 & 1.31 & 5.38 & 3.35 & & & 1.28 & 5.50 & 3.39 & & \\
\hline $\mathrm{Rp}_{1}$ & S2 & 3.42 & 7.28 & 5.35 & & & 3.35 & 7.45 & 5.40 & & \\
\hline \multirow[t]{3}{*}{$0.0 \mathrm{~g}$} & S3 & 3.43 & 9.47 & 6.45 & & & 3.36 & 9.85 & 6.61 & & \\
\hline & S4 & 4.45 & 9.74 & 7.10 & & & 4.32 & 10.13 & 7.23 & & \\
\hline & S5 & 12.37 & 18.96 & 15.67 & & & 12.00 & 19.72 & 15.86 & & \\
\hline \multirow[t]{2}{*}{$\mathrm{RP}_{1} * \mathrm{VAM}$} & & 5.00 & 10.17 & & 7.58 & & 4.86 & 10.53 & & 7.70 & \\
\hline & S1 & 1.61 & 6.45 & 4.03 & & & 1.56 & 8.00 & 4.78 & & \\
\hline $\mathrm{RP}_{2}$ & S2 & 4.62 & 9.68 & 7.15 & & & 4.48 & 12.00 & 8.24 & & \\
\hline \multirow[t]{3}{*}{$1.0 \mathrm{~g}$} & S3 & 5.17 & 10.89 & 8.03 & & & 4.60 & 13.50 & 9.05 & & \\
\hline & S4 & 5.45 & 10.74 & 8.10 & & & 4.85 & 13.32 & 9.09 & & \\
\hline & S5 & 0.00 & 18.96 & 9.48 & & & 0.00 & 23.51 & 11.76 & & \\
\hline \multirow[t]{2}{*}{$\mathrm{Rp}_{2} * \mathrm{VAM}$} & & 3.37 & 11.34 & & 7.3 & & 3.10 & 14.07 & & 8.58 & \\
\hline & S1 & 1.11 & 6.77 & 3.94 & & & 1.23 & 8.26 & 4.75 & & \\
\hline $\mathrm{Rp}_{3}$ & S2 & 3.02 & 9.78 & 6.40 & & & 3.35 & 13.69 & 8.52 & & \\
\hline \multirow[t]{3}{*}{$2.0 \mathrm{~g}$} & S3 & 3.63 & 11.63 & 7.63 & & & 4.03 & 16.28 & 10.16 & & \\
\hline & S4 & 3.77 & 11.89 & 7.83 & & & 4.18 & 16.65 & 10.42 & & \\
\hline & S5 & 10.88 & 20.04 & 15.46 & & & 12.08 & 28.06 & 20.07 & & \\
\hline \multirow[t]{3}{*}{$\mathrm{Rp}_{3} * \mathrm{VAM}$} & & 4.48 & 12.02 & & 8.2 & & 4.97 & 16.59 & & 10.78 & \\
\hline & S1 & 1.34 & 6.20 & & & 3.77 & 1.36 & 7.25 & & & 4.31 \\
\hline & S2 & 3.69 & 8.91 & & & 6.30 & 3.73 & 11.05 & & & 7.39 \\
\hline \multirow[t]{3}{*}{$\mathrm{S} * \mathrm{VAM}$} & S3 & 4.08 & 10.66 & & & 7.37 & 4.00 & 13.21 & & & 8.60 \\
\hline & S4 & 4.56 & 10.79 & & & 7.67 & 4.45 & 13.37 & & & 8.91 \\
\hline & S5 & 7.75 & 19.32 & & & 13.54 & 8.03 & 23.76 & & & 15.90 \\
\hline VAM & & 4.28 & 11.18 & & & & 4.31 & 13.73 & & & \\
\hline LSD at & \multirow{2}{*}{\multicolumn{2}{|c|}{ RP: 1.0365}} & & & & \multirow[t]{2}{*}{$\mathrm{S}=3.652$} & \multicolumn{2}{|c|}{$\mathrm{RP}=1.521$} & \multirow{2}{*}{\multicolumn{3}{|c|}{$\begin{aligned} S=4.877 \\
\mathrm{RP} * \mathrm{~S} * \mathrm{VAM}=5.254\end{aligned}$}} \\
\hline 0.05 & & & $\mathrm{RP} * \mathrm{~S} * \mathrm{I}$ & $\mathrm{M}=5$. & 369 & & VAM $=$ & 5.847 & & & \\
\hline
\end{tabular}


Table 12. Nitrogen $(\mathrm{N})$ content $(\%)$ of inoculated and uninoculated seedlings of Moringa oleifera Lam. with VAM, unfertilized and fertilized with RP under five levels of salinity

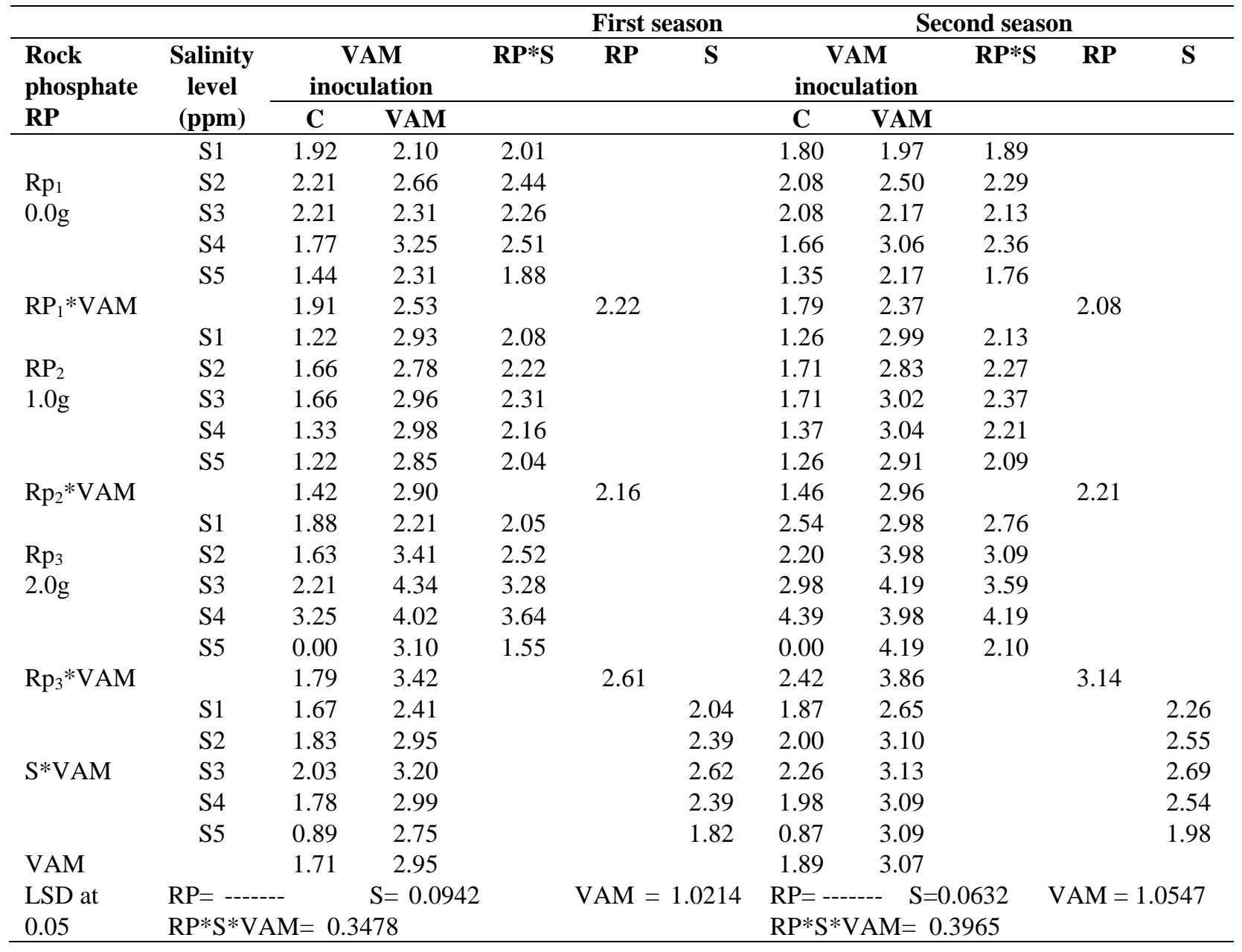

Table 13. Phosphorus (P) content $(\%)$ of inoculated and uninoculated seedlings of Moringa oleifera Lam. with VAM, unfertilized and fertilized with RP under five levels of salinity

\begin{tabular}{|c|c|c|c|c|c|c|c|c|c|c|c|}
\hline & & Fir & season & & & & & & nd seas & & \\
\hline $\begin{array}{l}\text { Rock } \\
\text { phosphate }\end{array}$ & $\begin{array}{c}\text { Salinity } \\
\text { level }\end{array}$ & inoc & $\begin{array}{l}\text { M } \\
\text { ation }\end{array}$ & $\mathbf{R P} * \mathbf{S}$ & $\mathbf{R P}$ & $\mathbf{S}$ & ino & $\begin{array}{l}\text { M } \\
\text { ation }\end{array}$ & $\mathbf{R P} * \mathbf{S}$ & $\mathbf{R P}$ & $\mathbf{S}$ \\
\hline $\mathbf{R P}$ & (ppm) & $\mathrm{C}$ & VAM & & & & $\mathrm{C}$ & VAM & & & \\
\hline & $\mathrm{S}_{1}$ & 0.25 & 0.39 & 0.32 & & & 0.25 & 0.37 & 0.31 & & \\
\hline $\mathrm{Rp}_{1}$ & $\mathrm{~S}_{2}$ & 0.19 & 0.46 & 0.33 & & & 0.22 & 0.44 & 0.33 & & \\
\hline $0.0 \mathrm{~g}$ & $\mathrm{~S}_{3}$ & 0.19 & 0.45 & 0.32 & & & 0.19 & 0.43 & 0.31 & & \\
\hline & $\mathrm{S}_{4}$ & 0.29 & 0.54 & 0.42 & & & 0.28 & 0.52 & 0.40 & & \\
\hline & $\mathrm{S}_{5}$ & 0.29 & 0.36 & 0.33 & & & 0.28 & 0.35 & 0.32 & & \\
\hline $\mathrm{RP}_{1} * \mathrm{VAM}$ & & 0.24 & 0.44 & & 0.34 & & 0.24 & 0.42 & & 0.33 & \\
\hline & $\mathrm{S}_{1}$ & 0.27 & 0.39 & 0.33 & & & 0.26 & 0.37 & 0.32 & & \\
\hline $\mathrm{RP}_{2}$ & $\mathrm{~S}_{2}$ & 0.20 & 0.52 & 0.36 & & & 0.20 & 0.50 & 0.35 & & \\
\hline $1.0 \mathrm{~g}$ & $\mathrm{~S}_{3}$ & 0.17 & 0.45 & 0.31 & & & 0.17 & 0.43 & 0.30 & & \\
\hline & $\mathrm{S}_{4}$ & 0.19 & 0.38 & 0.29 & & & 0.19 & 0.36 & 0.28 & & \\
\hline & $\mathrm{S}_{5}$ & 0.24 & 0.34 & 0.29 & & & 0.24 & 0.33 & 0.29 & & \\
\hline
\end{tabular}


Cont. Table 13.

\begin{tabular}{|c|c|c|c|c|c|c|c|c|c|c|c|}
\hline \multicolumn{7}{|c|}{ First season } & \multicolumn{5}{|c|}{ Second season } \\
\hline \multirow{2}{*}{$\begin{array}{l}\text { Rock } \\
\text { phosphate } \\
\text { RP }\end{array}$} & \multirow{2}{*}{$\begin{array}{c}\text { Salinity } \\
\text { level } \\
(\mathrm{ppm})\end{array}$} & \multicolumn{2}{|c|}{$\begin{array}{c}\text { VAM } \\
\text { inoculation }\end{array}$} & \multirow[t]{2}{*}{$\mathbf{R P} * \mathbf{S}$} & \multirow[t]{2}{*}{$\mathbf{R P}$} & \multirow[t]{2}{*}{$\mathbf{S}$} & \multicolumn{2}{|c|}{$\begin{array}{c}\text { VAM } \\
\text { inoculation }\end{array}$} & \multirow[t]{2}{*}{$\mathbf{R P} * \mathbf{S}$} & \multirow[t]{2}{*}{$\mathbf{R P}$} & \multirow[t]{2}{*}{$\mathbf{S}$} \\
\hline & & $\mathrm{C}$ & VAM & & & & $\mathbf{C}$ & VAM & & & \\
\hline \multirow{2}{*}{$\mathrm{Rp}_{2} * \mathrm{VAM}$} & & 0.21 & 0.42 & & 0.32 & & 0.21 & 0.40 & & 0.31 & \\
\hline & $S_{1}$ & 0.27 & 0.38 & 0.33 & & & 0.26 & 0.36 & 0.31 & & \\
\hline $\mathrm{Rp}_{3}$ & $\mathrm{~S}_{2}$ & 0.59 & 0.62 & 0.61 & & & 0.58 & 0.65 & 0.62 & & \\
\hline \multirow[t]{3}{*}{$2.0 \mathrm{~g}$} & $\mathrm{~S}_{3}$ & 0.19 & 0.83 & 0.51 & & & 0.19 & 0.84 & 0.52 & & \\
\hline & $\mathrm{S}_{4}$ & 0.41 & 1.46 & 0.94 & & & 0.40 & 1.40 & 0.90 & & \\
\hline & $\mathrm{S}_{5}$ & 0.00 & 0.20 & 0.10 & & & 0.00 & 0.19 & 0.19 & & \\
\hline \multirow[t]{3}{*}{$\mathrm{Rp}_{3} * \mathrm{VAM}$} & & 0.29 & 0.70 & & 0.50 & & 0.29 & 0.69 & & 0.51 & \\
\hline & & 0.26 & 0.39 & & & 0.33 & 0.26 & 0.37 & & & 0.31 \\
\hline & & 0.33 & 0.53 & & & 0.43 & 0.33 & 0.53 & & & 0.43 \\
\hline \multirow[t]{3}{*}{$\mathrm{S} * \mathrm{VAM}$} & & 0.18 & 0.58 & & & 0.38 & 0.18 & 0.57 & & & 0.38 \\
\hline & & 0.30 & 0.79 & & & 0.55 & 0.29 & 0.76 & & & 0.53 \\
\hline & & 0.18 & 0.30 & & & 0.24 & 0.17 & 0.29 & & & 0.26 \\
\hline VAM & & 0.25 & 0.52 & & & & 0.25 & 0.50 & & & \\
\hline LSD at & \multicolumn{3}{|c|}{$\mathrm{RP}=$------- } & & \multicolumn{2}{|c|}{$S=0.1963$} & $\mathrm{RP}=$ & \multirow{2}{*}{\multicolumn{2}{|c|}{$\begin{array}{c}S=0.1063 \\
M=0.2474\end{array}$}} & \multirow{2}{*}{\multicolumn{2}{|c|}{$\mathrm{VAM}=0.187$}} \\
\hline 0.05 & $\mathrm{VAM}=$ & & & $\mathrm{S} * \mathrm{VAN}$ & 0.215 & & $R P * S$ & & & & \\
\hline
\end{tabular}

Upon the significant interaction among the three factors studied. However, the highest $\mathrm{N}$ content $\%$ was obtained in the inoculated seedlings which applied with the third level of RP and treated with S3 level of salinity (4.34 and $4.19 \%$ for first and second season, respectively), the highest $\mathrm{K}$ content $\%$ was obtained in the inoculated seedlings which applied with the third level of RP and treated with S3 level of salinity in the (2.51 and $2.36 \%$ for first and second season, respectively) (Tables, 11 and 13), but the highest values of $\mathrm{P}$ were obtained at the fourth level of salinity $\mathrm{S}_{4}(1.46$ and $1.40 \%$ for first and second season, respectively), respectively. (Table 12).

Data showed in Table 14 that $\mathrm{Na}$ content increased with increases in $\mathrm{Na} \mathrm{Cl}$ levels, reaching the highest value $(0.55 \%$ and $0.53 \%)$ in the first and second season respectively for $\mathrm{Na} \mathrm{Cl} 171.1 \mathrm{mM}$, while, $\mathrm{Na}$ content decreased with increases in RP levels, reaching the lowest value $(0.0 .46 \%$ and $0.45 \%)$ in the first and second season respectively for $\mathrm{RP}_{3}(2 \mathrm{~g} / \mathrm{kg}$ soil). (Table 14).

These data are in accordance with those Ashraf and Orooj, 2006) and (Tabatabaie and Nazari, 2007). However, the relation between salinity and minerals nutrition of plants are very complex (Grattan and Grieve, 1999).

\section{DISCUSSION}

The obtained results showed that the inoculation with VAM and addition of RP led to enhance the growth significantly, in terms of $\mathrm{S}, \mathrm{SH}, \mathrm{SRR}, \mathrm{RDW}$,
SDW and TDW and minerals of the leaves of $M$. oleifera ( $\mathrm{N} \%, \mathrm{P} \%$ and $\mathrm{K} \%$ ) compared with the uninoculated ones. This may owing to the ability of mycorrhiza to increase root surface area to uptake mineral contents and make phosphorus absorpable by plant roots. This result was in agreement with the finding of Pagano et al. (2010) who reported that VAM colonization was significantly higher with the inoculated seedlings versus non-inoculated ones (control) and Tazisong et al. (2015) who said that Phosphatases are responsible for the hydrolysis of a range of organic $\mathrm{P}$ compounds and provide mineral phosphate to the plant. Furthermore, Matias et al. (2009) reported that the intensity of VAM colonization was also stimulated by plant growth.

It is worth noting that there is a significant decreasing of growth parameters with increasing in salinity level. These results in accordance with findings of Wang, et al., (2009); Ayse Sen and Sema Alikamanoglu (2011) and Omneya, et al. (2018).

Our results show that the increase of available $\mathrm{P}$ in rhizosphere was clearly related to the inoculation with the VAM treatment. Noteworthy, the increase in available $\mathrm{P}$ in the rhizosphere was clearly affected by VAM colonization in host plants. These findings are in match with Soon-Jae, et al. (2020).

The uptake of $\mathrm{N}$ and $\mathrm{P}$ was higher in VAM seedlings, and as the salinity increased, the trend showed a decline but had a clear upturn as the salinity stress increased to a high level (Dastogeer, et al., 2020). A number of reports emphasized the important role of mycorrhiza in 
Table 15. Sodium content Na (\%) of inoculated and uninoculated seedlings of Moringa oleifera Lam. with VAM, unfertilized and fertilized with RP under five levels of salinity

\begin{tabular}{|c|c|c|c|c|c|c|c|c|c|c|c|}
\hline \multicolumn{7}{|c|}{ First season } & \multicolumn{5}{|c|}{$\begin{array}{l}\text { Second season } \\
\end{array}$} \\
\hline \multirow{2}{*}{$\begin{array}{l}\text { Rock } \\
\text { phosphate } \\
\text { RP }\end{array}$} & \multirow{2}{*}{$\begin{array}{c}\text { Salinity } \\
\text { level } \\
\text { (ppm) }\end{array}$} & \multicolumn{2}{|c|}{$\begin{array}{c}\text { VAM } \\
\text { inoculation }\end{array}$} & \multirow[t]{2}{*}{$\mathbf{R P} * \mathbf{S}$} & \multirow[t]{2}{*}{$\mathbf{R P}$} & \multirow[t]{2}{*}{$\mathbf{S}$} & \multicolumn{2}{|c|}{$\begin{array}{c}\text { VAM } \\
\text { inoculation }\end{array}$} & \multirow[t]{2}{*}{$\mathbf{R P} * \mathbf{S}$} & \multirow[t]{2}{*}{$\mathbf{R P}$} & \multirow[t]{2}{*}{$\mathbf{S}$} \\
\hline & & $\mathbf{C}$ & VAM & & & & $\mathbf{C}$ & VAM & & & \\
\hline & $\mathrm{S}_{1}$ & 0.49 & 0.42 & 0.46 & & & 0.49 & 0.39 & 0.44 & & \\
\hline $\mathrm{Rp}_{1}$ & $\mathrm{~S}_{2}$ & 0.49 & 0.46 & 0.48 & & & 0.49 & 0.43 & 0.46 & & \\
\hline \multirow[t]{3}{*}{$0.0 \mathrm{~g}$} & $\mathrm{~S}_{3}$ & 0.56 & 0.55 & 0.56 & & & 0.57 & 0.51 & 0.54 & & \\
\hline & $\mathrm{S}_{4}$ & 0.62 & 0.58 & 0.60 & & & 0.63 & 0.54 & 0.59 & & \\
\hline & $\mathrm{S}_{5}$ & 0.73 & 0.66 & 0.70 & & & 0.74 & 0.61 & 0.68 & & \\
\hline \multirow[t]{2}{*}{$\mathrm{RP}_{1} * \mathrm{VAM}$} & & 0.58 & 0.53 & & 0.56 & & 0.58 & 0.50 & & 0.54 & \\
\hline & $\mathrm{S}_{1}$ & 0.49 & 0.42 & 0.46 & & & 0.49 & 0.39 & 0.44 & & \\
\hline $\mathrm{RP}_{2}$ & $\mathrm{~S}_{2}$ & 0.49 & 0.46 & 0.48 & & & 0.49 & 0.43 & 0.46 & & \\
\hline \multirow[t]{3}{*}{$1.0 \mathrm{~g}$} & $\mathrm{~S}_{3}$ & 0.56 & 0.49 & 0.53 & & & 0.57 & 0.46 & 0.52 & & \\
\hline & $\mathrm{S}_{4}$ & 0.57 & 0.54 & 0.56 & & & 0.58 & 0.50 & 0.54 & & \\
\hline & $\mathrm{S}_{5}$ & 0.70 & 0.60 & 0.65 & & & 0.71 & 0.56 & 0.64 & & \\
\hline \multirow[t]{2}{*}{$\mathrm{Rp}_{2} * \mathrm{VAM}$} & & 0.56 & 0.50 & & 0.53 & & 0.57 & 0.47 & & 0.52 & \\
\hline & $\mathrm{S}_{1}$ & 0.44 & 0.42 & 0.43 & & & 0.44 & 0.39 & 0.42 & & \\
\hline $\mathrm{Rp}_{3}$ & $\mathrm{~S}_{2}$ & 0.49 & 0.46 & 0.48 & & & 0.49 & 0.43 & 0.46 & & \\
\hline \multirow[t]{3}{*}{$2.0 \mathrm{~g}$} & $\mathrm{~S}_{3}$ & 0.53 & 0.48 & 0.51 & & & 0.54 & 0.45 & 0.50 & & \\
\hline & $\mathrm{S}_{4}$ & 0.63 & 0.55 & 0.59 & & & 0.64 & 0.51 & 0.58 & & \\
\hline & $\mathrm{S}_{5}$ & 0.00 & 0.60 & 0.30 & & & 0.00 & 0.56 & 0.28 & & \\
\hline \multirow[t]{3}{*}{$\mathrm{Rp}_{3} * \mathrm{VAM}$} & $\mathrm{S}_{1}$ & 0.42 & 0.50 & & 0.46 & & 0.42 & 0.47 & & 0.45 & \\
\hline & $\mathrm{S}_{2}$ & 0.47 & 0.42 & & & 0.45 & 0.47 & 0.39 & & & 0.43 \\
\hline & $\mathrm{S}_{3}$ & 0.49 & 0.46 & & & 0.48 & 0.49 & 0.43 & & & 0.46 \\
\hline \multirow[t]{3}{*}{ S*VAM } & $\mathrm{S}_{4}$ & 0.55 & 0.51 & & & 0.53 & 0.56 & 0.47 & & & 0.52 \\
\hline & $\mathrm{S}_{5}$ & 0.61 & 0.56 & & & 0.58 & 0.62 & 0.52 & & & 0.57 \\
\hline & & 0.48 & 0.62 & & & 0.55 & 0.48 & 0.58 & & & 0.53 \\
\hline VAM & & 0.52 & 0.51 & & & & 0.52 & 0.48 & & & \\
\hline LSD at & \multirow{2}{*}{\multicolumn{3}{|c|}{$\begin{array}{lr}\text { RP: } 0.02 & S=0.094 \\
R P * S * V A M=0.13\end{array}$}} & & \multirow{2}{*}{\multicolumn{2}{|c|}{$\mathrm{VAM}=0.0076$}} & \multicolumn{2}{|c|}{$\mathrm{RP}=0.03$} & & \multirow{2}{*}{\multicolumn{2}{|c|}{$\begin{aligned} & S=0.075 \\
I= & 0.16\end{aligned}$}} \\
\hline 0.05 & & & & & & & VAM & 0.0095 & $\mathrm{RP} * \mathrm{~S} *$ & & \\
\hline
\end{tabular}

In the present study, we found a significant increase in proline accumulation in both seasons under the highest salinity level, especially that supplemented by the aid of symbiotic agents such as mycorrhiza as it is in our study and also Frankia (El-Settawy and Ei-Gamal, 2009). In addition, M. oleifera plants can synthesize proline, they have been shown to take up exogenous proline and accumulate it Omneya, et al., (2018). Synthesis of amino acids is very important, notably, proline, glutamic (Flowers et al., 1977 and Fayek. et al., 2010 and Dastogeer, et al., 2020) and glycine betaine (Subbarao and Parvaize 2001) to create cellular osmotic balance, it is well known that the amino acis , proline is increased considerably under salinity stress and it could reached 200 fold that of plants in normal conditions (Elevin et al., 2019 and Xie, et al., 2020)

Finally, our results support the significant roles of rock phosphate in the alleviation of salt stress and enhancing soil quality for better symbiosis efficiency and yield obtained of M. oleifera.

\section{CONCLUSIONS AND RECOMMENDATIONS}

The present study concluded that (M. oleifera Lam.) could tolerate salt concentration up to $171.1 \mathrm{mM}$ in presence of mycorrhiza. Negative relationship was shown between salt stress degree and plant growth parameters, expressed as SH, RDW, SRR, SDW and RDW which decreased as the salt concentration increased.

Therefore, is recommended, however, to inoculate the seedlings with VAM and rock-phosphate application $\mathrm{RP}_{2}(1 \mathrm{~g} / \mathrm{kg}$ soil) to enhance its growth and to gain tolerance against salinity stress. 


\section{REFERENCES}

Abd_Allah, E. F., A.Hashem, A. A. Alqarawi, A. H.Bahkali, and M. S.Alwhibi. 2015. Enhancing growth performance and systemic acquired resistance of medicinal plant Sesbania sesban (L.) Merr using arbuscular mycorrhizal fungi under salt stress. Saudi J. Bio. Sci. 22:274-283.

Aebi, H. 1984. Catalase in vitro. Methods in Enzymol. 105:121-126.

Ahmad, P. 2010. Growth and antioxidant responses in mustard (Brassica juncea L.) plants subjected to combined effect of gibberellic acid and salinity. Arch. Agro. Soil Sci. 56:575588. doi: 10.1080/03650340903164231.

Ahmad, P., A.Hashem, E. F.Abd-Allah, A. A.Alqarawi, R.John and D.Egamberdieva. 2015. Role of Trichoderma harzianum in mitigating $\mathrm{NaCl}$ stress in Indian mustard (Brassica juncea L.) through antioxidative defense system. Front. Plant Sci. 6:868. doi:10.3389/fpls.2015.00868.

Alia, K.V., S.K. Prasad and P.P. Saradhi. 1995. Effect of zinc on free radicals and proline in Brassica and Cajanus. Phytochem. 39:45-47.

Alqarawi, A. A., E. F.Abd_Allah and A.Hashem. 2014. Alleviationofsalt-

inducedadverseimpactviamycorrhizalfungiin

Ephedraaphylla Forssk. J. PlantInter. 9: 802 - 810. doi:10.1080/17429145.2014.949886.

Alscher, R.G., N. Erturk and L.S. Heath. 2002. Role of superoxide dismutases (SODs) in controlling oxidative stress in plants. J. Exp Bot 53:1331-1341.

Amel, S. B., L.Mourad, M. O. Sidi, D.Nadjib and L.Hakim. 2019. Study of the Interaction Salinity: Phosphorus Fertilization on Sorghum. J. of Plant Growth Regulation . 39:1205-1210.

Armengaud, P., L.Thiery, N.Buhot, G.Grenier-De March and A. Savouré. 2004. Transcriptional regulation of proline biosynthesis in Medicago truncatula reveals developmental and environmental specific features. Physiol Plant. 120:442-450.

Aroca, R., J. M.Ruiz-Lozano, A.Zamarreno, J. A.Paz, J.M.Garcia-Mina and M.J.Pozo. 2013. Arbuscular mycorrhizal symbiosis influences strigolactone production nunder salinity and alleviates salt stress in lettuce plants. J.Plant Physiol. 170:4755.doi:10.1016/j.jplph.2012.08.020.

Ashraf, M. and M.R. Foolad. 2007. Roles of glycine betaine and Proline in improving plant abiotic stress resistance. Envir and Exp Bot. 59(2):206-216.

Ayse, S. and A.Sema. 2011. Effect of salt stress on growth parameters and antioxidant enzymes of different wheat (Triticum aestivum L.) varieties on in vitro tissue. Fresenius Environmental Bulletin PSP V. 20 - No 2a.

Barnawal, D., N.Bharti, D.Maji, C. S.Chanotiya and A.Kalra. 2014. ACC deaminase-containing Arthrobacter protophormiae induces $\mathrm{NaCl}$ stress tolerance through reduced ACC oxidase activity and ethylene production resulting in improved nodulation and mycorrhization in Pisum sativum. J. Plant Physiol. 171:884-894. doi: 10.1016/j.jplph.2014.03.007.
Chapman, H.D. and P.F. Pratt. 1961. Methods of Analysis for Soils, Plants and Waters. Agric. Pub. Univ. of California, Riverside, USA.

Chen Xiaoyang and Bin Su. 2020. Current Status and Potential of Moringa oleifera Leaf as an Alternative Protein Source for Animal Feeds. 7-53.

Dastogeer, M. G. K. , Mst Ishrat Zahan, Md. Tahjib-UlArif, Mst Arjina Akter and Shin Okazaki. 2020. Plant Salinity Tolerance Conferred by Arbuscular Mycorrhizal Fungi and Associated Mechanisms: A Meta-Analysis. Frontiers Plant Sci., 11. Article588550.

Dudhane, M., M. Borde and P.K. Jite. 2011. Changes in antioxidant activity in Gmelina arborea (Verbenaceae) inoculated with Glomus fasciculatum under drought stress. Archives Phytopath Plant Protect. 44(2):113-126.

El-Settawy, A.A. A. and A. S. EL-Gamal Amal. 2009. Influence of nodule-inducing Frankia on salinity tolerance of Casuarina glauca sieber ex spring plants and rhizosphere remediation. 34 (6): 7409-7434.

Evelin, H., R. Kapoor and B. Giri. 2009. Arbuscular mycorrhizal fungi in alleviation of salt stress: a review. Ann Bot. 104:12631280.

Evelin, H., B.Giri and R.Kapoor. 2011. Contribution of Glomus intraradices inoculation to nutrient acquisition and mitigation of ionic imbalance in $\mathrm{NaCl}$-stressed Trigonella foenum-graecum. Mycorrhiza. 1-15.

Evelin, H., S. D.Thokchom, G.Samta and K.Rupam. 2019. Mitigation of Salinity Stress in Plants by Arbuscular Mycorrhizal Symbiosis: Current Understanding and New Challenges. Front Plant Sci. 10: 470.

Fayek, M. A., E. A.Shaaban, N. S. Zayed, A. A. ElObeidy and R. A.Taha. 2010. Effect of salt stress on chemical and physiological contents of jojoba (Simmondsia chinensis (Link) Schneider) using in vitro culture. World J. of Agricultural Sci. 2010 Vol.6 No.4 pp.446-450.

Flowers, T.J., P.F.Troke, A.R. Yeo. 1977. The mechanism of salt tolerance in halophytes. Annu. Rev. Plant Physiol. 28:89-121.

Food and Agriculture Organization [FAO]. 2015. Status of the Worlds's Soil Resources (SWSR) - Main Report, United Nations. Rome: Food and Agriculture Organization.

Hasegawa, P.M., R.A. Bressan, J.K. Zhu and H. Bohnert. 2000. Plant cellular and molecular responses to high salinity. Ann Rev Plant Mol Biol. 51:463-499.

Hayat, M. A. 1991. Principles and Techniques of Scanning Electron Microscopy. Van Nostrand Reinhold.

Heikham, E., S. D.Thokchom, G.Samta and K.Rupam. 2019. Mitigation of salinity stress in plants by arbuscular mycorrhizal symbiosis: current understanding and new challenges. Plant Sci. 10. 470.

Hernandez, J.A., E. Olmos, G.J. Corpas, F. Sevilla and L.A. del Rio. 1995. Salt induced oxidative stress in chloroplast of pea plants. Plant Sci. 105:151-167.

Hildebrandt, U., M. Regvar and H. Bothe. 2007. Arbuscular mycorrhiza and heavy metal tolerance. Phytochem. 68:139146. 
Jama, M. A. and H.Yucel. 1989. Equilibrium Studies of Sodium-Ammonium, Potassium-Ammonium, and Calcium-Ammonium Exchanges on Clinoptilolite Zeolite. Separation Sci. and Technology. (24): 1393- 1416.

Kemble, A.R. and H.T. MacPherson. 1954. Liberation of amino acids in perennial ray grass during wilting. Biochem J. 58:46-59.

Lowry, O.H., N.R. Roberts, W.S. Mei-Ling and E.J. Crawford. 1954. The quantitative histochemistry of brain II. Enzyme measurements. J. Biological Chem. 207:19-37.

Mansour, M.M.F. and K.H.A. Salama. 2004. Cellular basis of salinity tolerance in plants. Environ Exp Bot. 52:113-122.

Marin, J.A., P.Andreu, A.Carrasco and A.Arbeloa. 2009. Prolina en tejidos y exudados de raíz como respuesta alestrés salino de cultivos de raíces aisladas de patrones frutales del género Prunus. ITEA-Información Técnica Económica Agraria. 105: 282-290.

Matias, S. R., P.Marcela Cláudia, C. M. Frederico, A. Christiane Oliveira, A. C. Andrea, H. Sa' Nadja and R. S. Maria. 2009. Effect of rhizobia, mycorrhizal fungi and phosphate-solubilizing microorganisms in the rhizosphere of native plants used to recover an iron ore area in Brazilq. European J. of Soil Biology. 45:259-266.

Matthew, Ch. E. and O.B. Olubukola . 2018. The influence of plant growth-promoting rhizobacteria in plant tolerance to abiotic stress: a survival strategy. Applied Microbiology and Biotechnology . (102):7821-7835.

Miransari, M., H.A. Bahrami, F. Rejali and M.J. Malakouti. 2008. Using arbuscular mycorrhiza to reduce the stressful effects of soil compaction on wheat (Triticum aestivum L.) growth. Soil Biol Biochem. 40:1197-1206.

Muthukumarasamy, M. and R. Panneerselvam. 1997. Amelioration of $\mathrm{NaCl}$ stress by triadimefon in peanut seedlings. Plant Growth Regul. 22:157-162.

Nagata, M. and I. Yamashta. 1992. Simple method for simultaneous determination of chlorophyll and carotenoids in tomato fruit. J. Japanese Soc. Food Sci. Technol. 39: 925-928.

Olsen, S.R. and L.E. Sommers. 1982. Phosphorus. In: Page, A.L., Ed., Methods of Soil Analysis Part 2 Chemical and Microbiological Properties, American Society of Agronomy, Soil Sci. Society of America, Madison. 403430.

Omneya, F. A. El., S.A. El. Nahed and A.A. El.Esam. 2018. Effect of proline on growth and the active ingredients of Moringa oleifera lam. plant under salt stress. N. Egypt. J. Microbiol.. 51: 56-85.

Ortas, I., O.Ustuner. 2014. Determination of different growth media and various mycorrhizae species on citrus growth and nutrient uptake. Sci. Horticulturae. 166: 84-90.

Pagano, M.C., M.N. Cabello and M.R.Scotti. 2010. Arbuscular mycorrhizal colonization and growth of Eremanthus incanus Less. in a high land field. Plant Soil and Environment. 56: 412-418.
Phillips, J.M. and D.S. Hayman. 1970. Improved procedures for clearing roots and staining parasitic and vesicular arbuscular mycorrhizal fungi for rapid assessment of colonization.Trans Br Mycol Soc. 55:158-160.

Porcel, R., R.Aroca and J.M. Ruiz-Lozano. 2012. Salinity stress alleviation using arbuscular mycorrhizal fungi. A review. Agron. Sust. Dev. 32:181-200. doi: 10.1007/s13593-011-0029-x

Prochazkova, D., K. S. Raj and Srivastava. 2001. Oxidative stress and antioxidant activity as the basis of senescence in maize leaves. Plant Sci. 161(4):765-771.

Putter, J. 1974. Peroxidase. In: Bergmeyer HU (Ed.). Methods of enzymatic analysis. Academic Press. NewYork. 5671124.

Ruiz-Lozano, J. M., R.Porcel, R.Azcon and R. Aroca. 2012. Regulation by arbuscular mycorrhizae of the integrated physiological response to salinity in plants. New challenges in physiological and molecular studies. J. Exp. Bot. 63:4033-4044. doi: 10.1093/jxb/ers126.

SAS Institute Inc. 2007. SAS Technical report SAS/STAT software: Changes and Enhancements Users Guide, 2(9):.1.3. Fourth Edition, Gary, NC: SAS Institute Inc.

Shen, M. , T.Ming, Ch.Hui, Y.Baowei , Z.Fengfeng and H.Yanhui . 2008. Influence of arbuscular mycorrhizae on photosynthesis and water status of maize plants under salt stress. Mycorrhiza . 18: 287-296.

Sheng, X.R., C. Brawley and E. Matunis. 2008. Live Imaging of Drosophila Spermatogonia Dedifferentiating into Germline Stem Cells. A. Dros. Res. Conf. 49 : 69.

Shrivali, B., V. Chinnuswamy, R.K. Chopra. 2003. Antioxidant defense in response to abiotic stresses in plants. J. Plant Biol. 30:121-139.

Snedecor, G. W. 1956. Statistical Methods. The Iowa State Univ. Press Ames. Iowa. U.S.A.

Soon-Jae, L., K.Mengxuan, M. St-Arnaud and H. Mohamed. 2020. Arbuscular Mycorrhizal Fungal Communities of Native Plant Species under High Petroleum Hydrocarbon Contamination Highlights Rhizophagus as a Key Tolerant Genus. Microorganisms. 8.872.

Subbarao, S. and A.Parvaiz. 2001. Salt stress and phytobiochemical responses of plants - a review A. Parvaiz, S. Satyawati. Plant Soil Environ. 54 (3): 89-99.

Szabados, L. and A.Savoure. 2009. Proline: A multifunctional amino acid. Trends in Plant Sci. 15(2):89-97.

Tabatabaie, S.J. and J. Nazari. 2007. Influence of nutrient concentrations and $\mathrm{NaCl}$ salin-ity on the growth, photosynthesis, and essential oil content of peppermint and lemon verbena. Turk. J. Agric. 31: 245-253.

Tazisong, I.A., Z.N. Senwo, and Z. He. 2015. Phosphatasehydrolysisoforganic phosphoruscompounds. Adv.Enz.Res. 3:39-51.doi:10.4236/aer.2015.32005

United Nations [UN]. 2018. World Population Report. NewYork, NY: United Nations.

Van Breusegem, F., E. Vranova, J.F. Dat and D. Inze. 2001. The role of active oxygen species in plants signals transduction. Plant Sci. 161:405-414. 
Verbruggen, N. and C. Hermans. 2008. Proline accumulation in plants: a review. Amino Acids. 35:753-759.

Wang, W.B., Y.H. Kim, H.S. Lee, K.Y. Kim, X.P. Deng and S.S. Kwak. 2009. Analysis of antioxidant enzyme activity during germination of alfalfa under salt and drought stresses. Plant Physiol. Biochem. 47(7):570-577.

Wasif, N., T. S. Muhammad, M. A. b.Shahzad, A. kh.Rashid, G.Tehseen, E. O. Mark and M. Hassan. 2012. Response of Moringa oleifera to Saline Conditions. International J. of Agriculture \& Biology. 5: 757-762.

Wu, Q. S., Z.Ying-Ning and E. F. Abd-Allah. 2014. "Mycorrhizal Association and ROS in Plants," in Oxidative Damage to Plants, ed P. Ahmad (New York, NY: Academic Press; Elsevier).453-475.
Xie En, X. W., D.Aizhong, Z.Lei, W. Xiaona and A. Bruce. 2020. Short-Term Effects of Salt Stress on the Amino Acids of Phragmites australis Root Exudates in Constructed Wetlands. Water.12.569.

Zeng Chenhang. 2013. Optimal Advance Selling Strategy under Price Commitment. Pacific Economic Review. 26: 233-258.

Zhu, J K. 2001. Plant salt tolerance Trends Plant Sci. 6(2):6671.

Zhu, J.K. and L. Xiong. 2002. Molecular and genetic aspects of plant responses to osmotic stress. Plant Cell and Environment. 25(2):131-139. 


\title{
الملخص العربي
}

\section{تأثثر فطر الميكوريزا الحوبصلية الثجيرية وإضافة صخر الفوسفات على نمو وإلكتلة الحيوية لثتلات المورينجا اوليفرا تحت الإجهاد الملحى}

\author{
مروة فرحات، محمد شحاته
}

P, K بالثتلات غير الملقحة بالميكوريزا.

أثرت معاملات كلوريد الصوديوم على محتوى الأوراق من

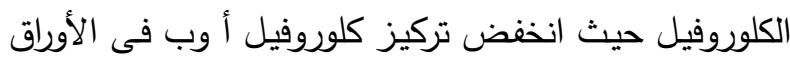

$$
\text { فى كلا موسمى النمو. }
$$

اوضـت النتائج أن أعلى تركيز للعناصر المعدنية في الاوراق كانت فى حالة المعاملة الثنائية للشتلات بالميكوريزا

$$
\text { وإضافة صخر الفوسفات. }
$$

كما اظهرت النتائج أن أعلى تركيز للبرولين فى شتلات

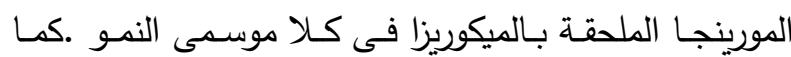
اتضـح مـن التجربـة أن شتلات المورينجـا يمكنهـا أن تتحمل موسيل تركيـز ملحسى عـالى يصـل إلى الى ميليمـول فـى وجـود

$$
\text { الميكوريزا. }
$$

ينصـح بأن يتم تلقيح شتلات المورينجـا بفطر الميكوريزا

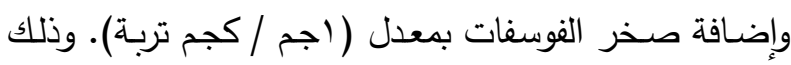
لزيادة سرعة النمو واكساب الشتلات تحملا للإجهاد الملحى. الكلمـات الدالـة: ملوحسة- بـرولين - ميكوريزا- مورينجـا-

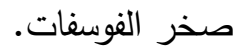

الملوحـة عامل إجهاد بيئى خطير يؤثر بشدة على نمو النباتات وتكثفها, وتسبب ملوحة التربـة غالبا تأخير الإنتاجية النباتية في كلا الحالتين الطبيعية والزراعيـة. فطر الميكوريزا الحويصـلية الثـيرية المتكافلـة يمكن أن يقلـل مـن الإجهاد النبـاتى النـاتج عـن الملوحـة وذلكك عـن طريـق زيـادة درجـة

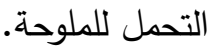

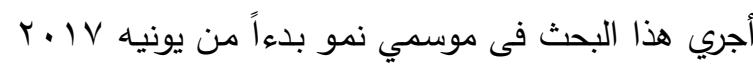

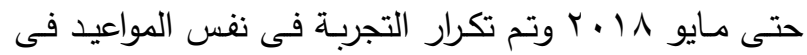
الموسم التالي وذلك بمشتل قسم الغابات وتكنولوجيا الأخشاب بمحطة البحوث الزراعية - كلية الزراعة - جامعة الإسكندرية بمنطقة ابيس وكذلك معامل قسم الغابات وتكنولوجيا الأخشاب بالكلية.

أوضـحت النتائج المتحصـل عليهـا أن التلقـيح بواسـطة VAM وإضـافة صـخر الفوسـات أدت إلىى تشـيع جـوهرى

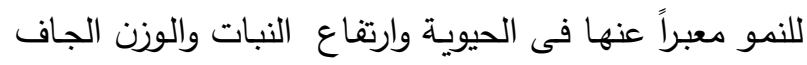
للمجموع الخضـرى والوزن الجـاف للجذر ونسبة السـاق الى على N, الجذر والوزن الجاف الكلى والعناصر المعدنية فى الأوراق 